\title{
Salinity dynamics of the Baltic Sea
}

Andreas Lehmann ${ }^{1}$, Kai Myrberg ${ }^{2,3}$, Piia Post ${ }^{4}$, Irina Chubarenko ${ }^{5}$, Inga Dailidiene ${ }^{6}$, Hans-Harald Hinrichsen ${ }^{1}$, Karin Hüssy ${ }^{7}$, Taavi Liblik ${ }^{8}$, Urmas Lips ${ }^{8}$, H. E. Markus Meier ${ }^{9}$, Tatiana Bukanova ${ }^{5}$

${ }^{1}$ GEOMAR Helmholtz Centre for Ocean Research Kiel, Germany

$5 \quad{ }^{2}$ Finnish Environment Institute/Marine Research Centre Helsinki, Finland

${ }^{3}$ Marine Research Institute, Klaipeda University, Klaipeda, Lithuania

${ }^{4}$ Institute of Physics, University of Tartu, Estonia

${ }^{5}$ Laboratory of Marine Physics, P.P.Shirshov Institute of Oceanology RAS, Kaliningrad, Russia

${ }^{6}$ Faculty of Marine Technology and Natural Sciences, Klaipeda University, Klaipeda, Lithuania

${ }^{7}$ National Institute of Aquatic Resources, Technical University of Denmark, Charlottenlund, Denmark

${ }^{8}$ Marine Systems Institute at Tallinn University of Technology, Tallinn, Estonia

${ }^{9}$ Leibniz Institute for Baltic Sea Research, Warnemünde, Rostock, Germany

Correspondence to: Andreas Lehmann (alehmann@geomar.de)

Abstract. In the Baltic Sea, salinity and its large variability, both horizontal and vertical, are key physical factors in determining the overall stratification conditions. In addition to that, salinity and its changes also have large effects on various ecosystem processes. Several factors determine the observed two-layer vertical structure of salinity. Due to the excess of river runoff to the sea, there is a continuous outflow of water masses in the surface layer with a compensating inflow to the Baltic in the lower layer. Also, the net precipitation plays a role in the water balance and consequently in the salinity dynamics. The salinity conditions in the sea are also coupled with the changes in the meteorological conditions. The ecosystem is adapted to the current salinity level: a change in the salinity balance would lead to ecological stress of flora and fauna, and related negative effects on possibilities to carry on sustainable development of the ecosystem. The Baltic Sea

25 salinity regime has been studied for more than 100 years. In spite of that, there are still gaps in our knowledge of the changes of salinity in space and time. An important part of our understanding of salinity are its long-term changes. However, the available scenarios for the future development of salinity are still inaccurate. We still need more studies on various factors related to salinity dynamics. Among others more knowledge is needed, e.g. from meteorological patterns in various space and time scales and mesoscale variability in precipitation. Also, updated information on river runoff and inflows of saline water is needed to close the water budget. We still do not understand accurately enough the water mass exchange between North Sea and Baltic Sea and within its sub-basins. Scientific investigations of the complicated vertical mixing processes are additionally required. This paper is a continuation and update of the BACC II book which was published in 2015, including information from articles issued until 2012. After that, there have been many new publications on the salinity dynamics, not least because of the Major Baltic Inflow which took place in December 2014. Several key topics have been investigated, including the coupling of long-term variations of climate with the observed salinity changes. Here the focus is on observing and indicating the role of climate change for salinity dynamics. New results of MBI-dynamics and related water mass 
interchange between the Baltic Sea and the North Sea have been published. Those studies also included results from the MBI-related meteorological conditions, variability in salinity and exchange of water masses between various scales. All these processes are in turn coupled with changes in the Baltic Sea circulation dynamics.

\section{Introduction}

The Baltic Sea salinity is not only a physical variable, but it also describes in an integrated way the simultaneous effects of the energy and water cycles in the sea; some of these features are just typical for the Baltic Sea, as the low mean level of salinity and its pronounced variability. Several factors determine the observed structure of salinity. Due to the excess of river runoff to the sea, there is a continuous outflow of water masses in the surface layer. A compensating inflow to the Baltic Sea takes place from the Kattegat through the Danish Straits in the lower layer, strongly governed by the local atmospheric conditions. Also, the net precipitation over the sea plays a role in the water balance and consequently in the salinity dynamics. An essential role in salinity dynamics is played by the barotropic water exchange which comprise irregularly Major Baltic Inflows (MBIs, Matthäus and Franck, 1992) and Large Volume Changes (LVCs, Lehmann et al., 2017). These inflows have a significant impact on the modification of the observed patterns of stratification and oxygen conditions.

50 The Baltic Sea salinity regime has been studied for more than 100 years. Despite this long research history, there are still gaps in our knowledge of salinity changes, both in space and time. Due to that, the available scenarios for the future are still inaccurate. The projections indicate that precipitation will increase during the forthcoming decades. Hence, the ensemble mean of available scenarios shows a decrease of salinity by about $0.6 \mathrm{~g} \mathrm{~kg}^{-1}$ until 2100 . The global rise of sea level has not been taken into account in these assumptions for the future (Saraiva et al., 2019b). Due to the uncertainties in water balance estimates, there are inaccuracies in the climatic model scenarios: whether the Baltic Sea salinity will decrease, or increase is still an open question. The Baltic Sea ecosystem is adapted to the current salinity level: a change in the salinity balance would lead to ecological stress of flora and fauna and related negative effects on possibilities to carry on sustainable development of the ecosystem (e.g. Vuorinen et al., 2015).

BACC II book (BACC II Author Team 2015; Elken et al. 2015) includes the review of the salinity dynamics based on 60 publications till 2012. After that, especially the Baltic Earth community has encouraged scientist to publish new results on that issue. In December 2014, a Major Baltic Inflow took place and afterwards, several papers were devoted to study various aspects of such inflow events (see Mohrholz, 2015, Gräwe et al. 2015, Rak, 2015). Those studies revealed new results on multiple factors not only concerning MBIs. Such are: the link between long-term (decadal-scale) variability in climatic conditions with the salinity development in the Baltic Sea, MBIs and related barotropic exchange of mass and

65 meteorological forcing conditions, variations in salinity and fluxes on various scales (observation and attribution to changes in climate), salt budget changes and the related variations in the Baltic Sea circulation and induced changes in oxygen conditions. 
This paper is organized as follows. First, we summarize the knowledge which has been collected and summarized in BACC I (BACC Author Team, 2008) and BACC II (BACC II Author Team, 2015) books and e.g. in Leppäranta and Myrberg (2009) and Omstedt et al. (2014). Additionally, we assess recent publications and knowledge following the BACC-process after 2012. This part starts with describing the atmospheric forcing which is driving the salinity dynamics, followed by a detailed update of the knowledge of salinity dynamics. Further on, we study new features of salinity dynamics on regional scale concerning the sub-basins surrounding the Baltic Proper (Fig. 1). The various sub-basins respond differently to the changing atmospheric conditions. So, we highlight observed similarities and differences. Further, we summarize climate change impact on salinity dynamics. Following that, oxygen conditions are analyzed in the central deep areas, being directly related to the dynamics of salinity. Thus, an improved understanding of the salinity dynamics will also deepen our knowledge of the processes concerning oxygen. Additionally, the salinity dynamics is also related to the environmental conditions of the marine ecosystem, like fisheries, etc., in the Baltic Sea, which is discussed, too. The paper ends with discussing existing knowledge gaps and by giving key messages of our present understanding of salinity dynamics and suggesting necessary further work.

\section{Salinity dynamics of different space and time scales - knowledge from BACC I and BACC II}

Salinity dynamics have been discussed in both BACC books (BACC I Author team, 2008; BACC II Author Team, 2015) and, e.g. in Leppäranta and Myrberg (2009) and Omstedt et al. (2014). We will summarize here the earlier findings of salinity dynamics to set up the basis of our current understanding:

- There was a decreasing trend of the mean salinity of the Baltic Sea both in the early 1900s and later during the century (1980s and 1990's); the latter is coupled with a complete lack of MBIs during 1983-1993. During those periods, freshwater inflows were more extensive than on average and zonal winds were stronger than normal, showing a very long-term natural variability in the highly dynamic system. During the stagnation periods with lower than normal salinities, the lack of inflows led to the situation where the ventilation in the Gotland basin was weak below the halocline. As a consequence of that, hypoxic bottom areas formed. However, towards the end of the period without inflows, the hypoxic area was shrinking because of the deepening and weakening of the halocline. For example, in the Gulf of Finland, the halocline completely disappeared, and the bottom oxygen conditions improved. However, despite the abrupt changes in salinity, there was no clear trend for the vertical mean salinity, if to consider the entire 20th century.

- During the last 2-3 decades, the surface-layer salinity was slightly lower than on average, supposed to be driven by higher accumulated river runoff.

- MBIs, usually of barotropic origin, occur in favorable meteorological conditions, such as mainly existing in winter and springtime. For an MBI to happen, there should be firstly winds from the east, and after such a period, 
winds should blow from the west for several weeks. The back-to-back occurrence of these two wind events is not very common in the Baltic Sea, which keeps the natural frequency of MBIs relatively low.

- Later, after 1996, a different type of inflow has been observed. Such events are baroclinicall-driven and take place during the summer period. In the same way as for barotropic events such inflows transport water with higher salinity and temperature to the Baltic deeper layers. But, as the inflowing water volume of higher salinity is small compared to MBIs, the water stratifies in the halocline, not able to substitute the bottom water. Summer inflows inject higher saline water with higher temperatures and low oxygen content into the halocline. Most probably, such events have occurred before but could not be observed due to shortcomings in the observational strategy.

\section{Atmospheric forcing driving the salinity dynamics of the Baltic Sea}

The large-scale atmospheric circulation controls the local weather conditions over the Baltic Sea area, which in turn drives the circulation in the Baltic Sea and the distribution of temperature, salinity and oxygen, which are relevant for biological production. Different weather regimes impact on the trophic structure and the marine food webs (Lehmann et al. 2002; Hinrichsen et al. 2007).

The speed and position of the Atlantic storm track or the polar jet stream is the most prominent feature that influences the variability of the atmospheric conditions in the Baltic Sea region. The influence of this storm track could be described in various space and time scales. The mean salinity of the Baltic Sea is controlled by long-term variations such as river runoff, dry and wet periods. At the same time, salinity variations on smaller scales are driven by shorter-term events like barotropic exchange flows. Starting from the largest, the continental or hemispheric scale, teleconnection patterns are commonly used to describe the atmospheric circulation variability. The best-known of them is the North Atlantic Oscillation (NAO), which is the first mode of principal component analysis of the sea level pressure (SLP) field over the North Atlantic/European sector (Hurrel, 1995). The East Atlantic (EA) pattern (Wallace and Gutzler, 1981) and the Scandinavian pattern (SCA), also termed Eurasian or blocking pattern, are described by the second and third mode, respectively (Hurrel and Deser, 2009). All these modes are better expressed in winter than in other seasons.

The NAO index or similar local indices (e.g. BSI - Baltic Sea Index, Lehmann et al., 2002), which describe the strength of the zonal atmospheric circulation, are often related to the intermittent water exchange between the North Sea and Baltic Sea through the Danish Straits. The popularity of the NAO resulted from its relatively close connection with the decadal variability of the seasonal circulation in the years 1960-1990 when the NAO index increased, and the correlation between the climatological variables in Northern Europe (including the Baltic Sea surface elevation) was very high (Pinto and Raible, 2012; Feser et al., 2015; Lehmann et al., 2017). But the link is non-stationary, and therefore this simple approximation does not work for all periods (Cassou et al., 2004; Matulla et al., 2008; Lehmann et al., 2017). The analysis of winter SLP data highlighted considerable changes in intensification and location of storm tracks, parallel with the eastward shift of the NAO 
centres of action (Cassou et al., 2004; Lehmann et al., 2011). At the same time, a seasonal shift of extreme wind events from autumn to winter and early spring was found in the Baltic area.

The strength of windstorms is undoubtedly crucial for the salinity dynamics of the Baltic Sea. Zubiate et al. (2016) characterized the variability of wind speed and distribution as a function of the NAO and the current states of the secondary (EA) and tertiary (SCA) patterns of the SLP variability over Europe. A strong correlation at monthly time scales has been found between the NAO positive phase and wind speed in northern Europe. But this effect combines with different other patterns that vary with sub-region. Over the Danish Straits, strong winds are associated with the combination of the $\mathrm{NAO}^{+}$, $\mathrm{EA}^{-}$and SCA${ }^{-}$phase, while over Scandinavia, the $\mathrm{NAO}^{+}$combined with $\mathrm{EA}^{+}$initiates more storms. The temporal clustering of windstorms, also an essential player in wind climatology, has different large-scale drivers dominating over the Danish Straits. There is a triple point of NAO, SCA, and the polar index (POL), with POL dominating in the northern flank and the SCA over the Baltic Sea's southern side (Waltz et al., 2018). All this refers that the Baltic Sea region is not homogeneous from the viewpoint of large-scale atmospheric variability. Thus, it is essential to investigate forcing patterns also at smaller scales.

The analysis of the synoptic-scale atmospheric circulation is based on classifying meteorological fields with various methods or tracking cyclones and anticyclones, mapping, and counting them (Barry and Carleton, 2013). Both kinds of approaches are applied to characterize the atmospheric conditions before, during, and after the events of large barotropic inflows or large volume changes (LVC, Lehmann et al., 2017). From earlier studies (e.g., Schinke and Matthäus, 1998), it could be deduced that the synoptic-scale atmospheric forcing, which is vital during inflow events, could be described and interpreted by the usage of automated weather types. Two different synoptic classifications have been applied (Lehmann and Post, 2015; Post and Lehmann, 2016). During different phases of the inflow event, the number of certain classes (directions of synoptic-scale airflow) increases or decreases compared to the average frequency of classes. About 60 days before the maximum inflow, which corresponds to the maximum sea surface elevation at Landsort, the frequency of eastern and southeastern classes increases for about 30 days. This confirms the results of Matthäus and Schinke (1994) about the pre-inflow period with prevailing easterly winds and less precipitation to enhance the outflow of Baltic Sea water lowering the mean sea level. At the same time, the wedge-shaped salinity front in the Danish Straits becomes more tilted by the movement of higher saline bottom water in the direction to the sill. An immediate period of very strong westerly winds starting about 30 days before the maximum inflow force effective LVCs/MBIs. Atmospheric forcing is more strongly associated with LVCs than MBIs, while it directly controls the sea level and indirectly the amount of salt of the inflowing water mass.

Barotropic inflow events like LVCs/MBIs are driven by a sequence or accumulation of atmospheric forcing (Lehmann et al., 160 2017). During barotropic inflow events, which last about 40 days, 5-6 temporal clustered deep cyclones move along characteristic pathways or storm tracks.

One possible reason for less frequent MBIs in the 1980s might be the increased atmospheric zonal circulation associated with increased precipitation and runoff at the expense of pre-inflow easterly wind periods (Schinke and Matthäus, 1998; Lehmann et al., 2002; Meier and Kauker, 2003; Lehmann et al., 2011). Soomere et al. (2015) proposed an alternative 
explanation. The meridional airflow direction over the southern Baltic Sea changed around 1987 to northwestern wind events at the expense of wind directions necessary for MBIs to occur.

\section{Update of the knowledge of salinity dynamics since 2012}

\subsection{Large Volume Changes and Major Baltic Inflows}

170 Despite a long history of Baltic Sea studies, still today, an important objective for investigations is the dynamics of water exchange between the North Sea and the Baltic Sea. A critical study objective is the transition area between the two seas: the Danish Straits.

Furthermore, pronounced changes of the salinity in the Gotland Deep, situated in the central Baltic, are strongly dependent on major salt water inflows, MBIs These events represent a specific type of barotropically-driven inflows. Their formation depends on specific favorable meteorological circulation patterns (e.g. Matthäus et al. 2008, Leppäranta and Myrberg, 2009; Lehmann and Post, 2015) and spatio-temporal grouping of deep cyclones (Lehmann et al., 2017).

There has recently been carried out a number of investigations about the role of meteorological forcing and its impact on the hydrographic conditions in the Danish Straits, and the total freshwater supply to the Baltic Sea before the occurrence of highly saline barotropically-driven inflows. Höflich and Lehmann (2018) proposed a mechanistic explanation including the salinity in the Danish Straits as well as the time-variability of meteorological forcing in connection to an inflow taking place. Freshwater supply played only a modulating role, i.e. it does not lead to a change in frequency nor intensity of the events. However, it had an adjusting role to observed transports of saline water to the Baltic Sea.

The third-largest ever observed MBI took place in December 2014, rising interest to study the saline inflows further (e.g. Mohrholz et al., 2015, Gräwe et al. 2015, Rak, 2016, Neumann et al., 2017, Liblik et al., 2017). Mohrholz (2018) re-analysed the time series of the Major Inflows. He used long-term data of sea levels, river runoff and observed salinity in the Belt and the Sound. As a result, an ongoing time series of barotropically-driven inflows was formed from about 1890 until today. The new time series by Mohrholz (2018) were compared with those composed by Fisher and Matthäus (1996). There were found apparent differences between the two series from the 1980s onwards. There were many reasons behind the observed deviations. Not much accurate data during the 1976-1991 period was available. After that time, the methods to observe the inflows were changed, which caused bias to the statistics. Moreover, the locations where the measurements took place were changed (Mohrholz, 2018).

There is a clear difference in the revised time series of the MBIs compared with the earlier ones. Namely, according to Mohrholz (2018), there is no clear trend in the frequency and intensity of the MBIs in the decadal time scale. In the traditional assumption, climate change would have impacted MBIs as decreasing trend in their frequency. On the other hand, there was found to be variability in the frequency of the inflows with a timescale of about 30 years (Mohrholz, 2018 and Radtke et al., 2020). 
This decadal variability was also found in surface and bottom salinities, river runoff and salt transport across the Darss Sill (Radtke et al. 2020). It also turned out that MBIs are not the only events which transport salt into the Baltic Sea. There are also smaller inflows of barotropic origin. These occur during all seasons having a low variability between the years. Such inflows bring about $30 \%$ of the entire salt transport to the Baltic Sea. This variability of the saline water inflows in time does not explain the worsening of oxygen conditions in the Gotland basin (anoxic bottoms) and the observed prolonged periods of stagnation (Mohrholz, 2018). Large barotropic inflows and the associated dense bottom currents form one branch of the Baltic Sea overturning circulation and deep-water ventilation. Holtermann et al. (2017) investigated the dynamics of the deep waters and vertical mixing in the central part of the Baltic Sea while Major Baltic Inflows took place; thus, providing new information on dense bottom gravity currents on their way to the deep central Baltic Sea and associated turbulent mixing. Liblik et al. (2018) studied the impact of MBIs downstream from the eastern Gotland Basin to the Gulf of Finland. A further study by Stramska and Aniskiewicz (2019) showed that remote sensing altimetry could be a complementary source of information about barotropic inflow events.

\subsection{The cold intermediate layer}

A Baltic-specific physical feature is the so-called Cold Intermediate Layer (hereafter denoted as CIL), which is formed annually. CIL appears as a temperature minimum between the thermocline and the permanent halocline from spring to autumn. Vertical convection, due to cooling of the atmosphere, and wind mixing erodes the seasonal thermocline during autumn and winter (Leppäranta and Myrberg, 2009, Stepanova, 2017). During this process, the water masses of the fresher upper layer and the sub-thermocline saltier layer are mixed. As a result, the seasonal salinity maximum in the surface layer occurs in winter (Reissmann et al., 2009). This mixing process extends down to the upper boundary of the permanent halocline (Fig. 2 and 3). In areas where the permanent halocline does not exist, such as the Gulf of Riga and the Gulf of Bothnia (Fig. 1), mixing leads almost every winter to a complete turnover of the entire water column (Raateoja, 2013; Raudsepp, 2001). With the formation of the seasonal thermocline, the CIL is formed as a separated layer between the thermocline and the permanent halocline. Its thickness has been estimated to be 20-50 m (Liblik and Lips, 2017; Stepanova, 2017). Despite the rapid warming of the thermal mixed layer, the temperature of the CIL only slowly increases during summer and autumn (Hinrichsen et al., 2007; Liblik and Lips, 2011). However, CIL can be traced in the water column until the next winter (Liblik et al., 2013; Stepanova, 2017), when a new CIL is formed. The water temperature in the CIL correlates with the severity of the previous winter (Hinrichsen et al., 2007; Liblik and Lips, 2011). After the formation of the thermocline in spring, CIL temperature is often lower than the temperature of maximum density (Tmd), most probably due to lateral advection of slightly higher saline, dense water. This buoyancy flux is stronger than the destabilizing effect caused by the warming of the water, when $\mathrm{T}<$ Tmd (Chubarenko et al., 2017; Eilola and Stigebrandt, 1998). 
https://doi.org/10.5194/esd-2021-15

Preprint. Discussion started: 4 June 2021

(c) Author(s) 2021. CC BY 4.0 License.

According to Chubarenko and Stepanova (2018), colder and slightly saltier water, which has its origin from the upper layer

of the Bornholm Basin, advects to the east and forms the core of the CIL. Wind-driven pycnocline variations, including coastal upwelling and downwelling events, considerably alter the depth and thickness of the CIL (Liblik and Lips, 2017). No remarkable changes have occurred in temperature and salinity in the CIL from 1982 to 2016 (Liblik and Lips, 2019).

\section{New knowledge of regional salinity dynamics}

\subsection{Salinity dynamics of the eastern Gotland Basin and the Gulf of Riga}

The eastern Gotland Basin as part of the Baltic Proper (Fig. 1) is the most prominent region to investigate the impact of barotropic inflows and long-term salinity changes in the Baltic Sea. The salinity dynamics of the eastern Gotland Basin is also affecting the different sub-basins and lagoons surrounding it. The salinity dynamics there represents with sufficient accuracy the development of salinity and stratification in the entire Baltic Proper. Changes in the mean salinity calculated from Gotland Deep's position are only about 2\% different from the calculation based on all sub-basins (Winsor et al. 2001, Winsor et al. 2003, Elken et al. 2015). Observed surface salinity of the eastern Gotland Basin (Fig. 2 and Fig. 4) reveals a low-salinity period starting in the 1980s (Elken et al. 2015, Vuorinen et al., 2015, Liblik and Lips 2019) and lasting until 2002. After the MBI in 2003, the surface salinity is slightly increasing and fluctuating until 2018, but it remains relatively low (<6.5 g kg-1; Fig. 4). The deepwater salinity decreased from the late 1970s until 1993 and then increased until 2018 (Fig. 2). Major saltwater inflows after 1994 can be traced by the abrupt salinity increase in the layers below the halocline. There are also smaller barotropic inflows (Mohrholz, 2018), keeping the salinity below the halocline on a high level (Fig. 2). A negative salinity trend of about $0.1-0.2 \mathrm{~g} \mathrm{~kg}^{-1}$ per decade can be detected at the surface. The surface temperature increases by about $0.4-0.6^{\circ} \mathrm{C}$ per decade, whereas surface oxygen decreases by $0.1-0.2 \mathrm{ml} \mathrm{l}^{-1}$ per decade (Fig. 3). Generally, the temperature trend at the surface of the Baltic Sea follows the trend in air temperature. Increasing temperatures reduce the solubility of oxygen, and at the same time, enhance oxygen depletion rates. Maximum negative trends in oxygen up to $1 \mathrm{ml}$ $\mathrm{I}^{-1}$ per decade can be found in the area of the halocline (Bornholm and Gotland Basin, Fig. 3). The surface salinity trend decreases, whereas salinity below the halocline increases (0.2-0.25 $\mathrm{g} \mathrm{kg}^{-1}$ per decade), leading to enhanced stratification between the surface and deep layer. However, the frequency of barotropic and Major Baltic Inflows did not increase. The decreasing trend in surface salinity might be due to increased runoff and net precipitation (Liblik and Lips, 2019). The volume-averaged salinity also shows a drop until 1992, and with the MBI in 1993, a gentle increase occurred (Fig. 4 and Fig. 5).

The Gulf of Riga is a seasonally stratified, semi-enclosed basin in the eastern Baltic Sea (Fig. 1), where the water column is fully mixed every autumn-winter. The gulf has two shallow connections with the Baltic Proper: the Irbe Strait (sill depth 25 $\mathrm{m}$ ) and the Väinameri sea area (sill depth $5 \mathrm{~m}$ ). The water budget in the gulf is determined by the water mass transport through these two openings (Laanearu et al., 2000; Lilover et al., 1998; Otsmann et al., 2001) and river discharge which is 
concentrated in the southern part of the gulf. Due to the shallow straits, the sub-halocline salty water does not intrude from the Baltic Proper to the gulf, and no permanent halocline exists there. Stratification in early spring is dominated by haline stratification (Stipa et al., 1999), especially close to the freshwater sources, but later in spring and summer, thermal stratification becomes more important in stabilizing the water column (Berzinsh, 1995; Liblik et al., 2017). Thus, the water column is stratified from spring to late autumn (Berzinsh, 1995), but the mean salinity difference between the upper and deep layers is only 0.7-1.0 $\mathrm{g} \mathrm{kg}^{-1}$ (Raudsepp, 2001; Skudra and Lips, 2017). There is quite a high correlation between river runoff in spring and mean salinity in the upper mixed layer in August (Skudra and Lips, 2017). Bottom layer salinity in the gulf is well-correlated with the near-bottom salinity in the Irbe Strait (Skudra and Lips, 2017). Long-term changes in the average salinity are characterized by an increase from the 1960s to the late 1970s and a consecutive decrease in the 1980s1990s (Berzinsh, 1995). The latter trend of decreasing salinity in the gulf coincided with the corresponding changes in the Baltic Proper in the layer above the halocline during the stagnation period until the mid-1990s (Raudsepp, 2001; Fig. 2 and 4).

Wind-driven processes modify the transport of saltier water from the Irbe Strait and the advection of riverine water (Liblik et al., 2017; Lips et al., 2016b, 2016c; Soosaar et al., 2014, 2016). Most of the freshwater from the Daugava River is transported to the north along the eastern shore during the cold season (Lips et al., 2016b). An anticyclonic gyre in the southern part of the gulf (Soosaar et al., 2014) or the entire gulf (Lips et al., 2016b) could form in spring-summer under specific wind forcing. Modeling experiments have also indicated that cyclonic eddies could develop and transport the saltier water from the Irbe Strait towards the central gulf (Lips et al., 2016c). High-resolution measurements have shown an entering of the sub-surface warmer, saltier, and oxygen-rich buoyant patches from the Irbe Strait into the gulf intermediate layer in summer. The exact shape, fate and impact of these sub-mesoscale features are unknown, but they showed up as strong subsurface salinity maxima in the time series (Liblik et al., 2017).

\subsubsection{Salinity dynamics of lagoons}

Some of the largest European lagoons (e.g., Curonian Lagoon, Vistula Lagoon, Szczecin Lagoon) situate in the Baltic Sea (Fig. 1). As the Baltic Sea can be considered a large estuary, the Gulf of Finland, the Gulf of Bothnia and the Gulf of Riga can be described as estuaries of medium-scale, and lagoons form the small-scale end. Common to all estuaries is the local circulation driven by the salinity difference inside and outside the estuary (Leppäranta and Myrberg, 2009). The salinity regime of lagoons is closely related to the water balance components, including river runoff, seawater inflows and intrusions, precipitation, and evaporation. All these water balance elements, as well as the air temperature, sea-surface temperature and sea level, are changing and can be expected to change in the future due to climate change in the Baltic Sea region. For instance, the warming trend of the mean surface water temperature in the south-eastern lagoons of the Baltic Sea was $0.03{ }^{\circ} \mathrm{C}$ year ${ }^{-1}$ in the period $1961-2008$ and about $0.05{ }^{\circ} \mathrm{C}_{\text {year }}{ }^{-1}$ after 1980 (Dailidiene et al., 2011; compare with Fig. 3). In the Curonian Lagoon and the Vistula Lagoon, the water level rose $18 \mathrm{~cm}$ between 1961 and 2008, corresponding to a rate of $\sim 4$ 
mm year ${ }^{-1}$ (Dailidiene et al., 2011). Furthermore, human activities such as river regulation, deepening port areas/inlets etc., can directly affect the water balance and salinity dynamics.

The Curonian Lagoon, located in the southeastern part of the Baltic Sea (Fig. 1), is the largest coastal shallow lagoon in Europe. It has a narrow connection to the Baltic Sea in the north (Klaipeda Strait with a width of 300-600 m). The lagoon receives freshwater discharge varying between $14 \mathrm{~km}^{3}$ year-1 to $33 \mathrm{~km}^{3}$ year'-1 (Jakimavičius et al., 2018) with the dominant contribution from the Nemunas river. The total river runoff to the lagoon is on average about $22 \mathrm{~km}^{3} \mathrm{year}^{-1}$, and it exhibits a strong seasonal pattern, peaking with snowmelt during the flood season in February-April (Jakimavičius et al., 2018). The water in the Curonian Lagoon is theoretically exchanged in about 80 days. In the southern and central parts, which are directly influenced by river runoff, salinity is only up to $0.05 \mathrm{~g} \mathrm{~kg}^{-1}$. In the northern part, salinity is fluctuating between 0 and $7.5 \mathrm{~g} \mathrm{~kg}^{-1}$. The inflow of saline water from the Baltic Sea depends on the meteorological conditions. Furthermore, due to dredging in the transition area to the Baltic Sea, the annual mean salinity is increasing. For example, winds blowing from north and north-east may lead to an inflow of saltier waters into the lagoons. The Baltic Sea water can reach the central Curonian Lagoon part even $40 \mathrm{~km}$ from the entrance during upwelling. Climate change projections reveal an increase in the Curonian Lagoon's salinity, linked to changes in water exchange through the Klaipėda Strait and the Nemunas runoff (Jakimavičius et al., 2018).

The Vistula Lagoon, the second largest lagoon in the Baltic Sea (Fig. 1), has an average salinity of $3.5 \mathrm{~g} \mathrm{~kg}^{-1}$, and the salinity may vary from $0.5 \mathrm{~g} \mathrm{~kg}^{-1}$ in the southern part up to $6.5 \mathrm{~g} \mathrm{~kg}^{-1}$ at the Baltyisk Strait. The water balance of the Vistula Lagoon was estimated by Rózyn'ski et al. (2018): yearly, $17 \mathrm{~km}^{3}$ (80.2\%) of water enter the lagoon through the Baltyisk Strait, riverine inflows amount to $3.62 \mathrm{~km}^{3}$ (17.1\%), atmospheric precipitation $0.5 \mathrm{~km}^{3}$ (2.4\%), evaporation $0.65 \mathrm{~km}^{3}$ (3.1\%), and groundwater inflows $0.07 \mathrm{~km}^{3}(0.3 \%)$. While the Curonian Lagoon has maintained the same environmental conditions over ages, the Vistula Lagoon experienced considerable anthropogenic modification at the end of the nineteenth century, evolving from a freshwater coastal lake to an estuarine lagoon with predominant marine influence (Chubarenko et al. 2017). There are plans for constructing a second inlet to the lagoon at the Polish side (Rózyn'ski et al., 2018) that could change the water balance of the lagoon in future.

The Szczecin Lagoon (Fig. 1) also belongs to one of the largest lagoons in Europe. The lagoon is shallow with an average depth of $3.8 \mathrm{~m}$ only. The salinity varies between 1 and $3 \mathrm{~g} \mathrm{~kg}^{-1}$, and the lagoon is connected with the Baltic Sea via three outlets (Friedland et al., 2019). The residence time of water in the Szczecin Lagoon is about 75 days. The sea surface temperature in the Curonian Lagoon is projected to increase by $2-6^{\circ} \mathrm{C}$ by the year 2100 (Jakimavičius et al., 2018). Water temperature and sea level rise could lead to an increase in salinity due to less restricted water exchange between the Baltic Sea and the lagoons. The average water level of the lagoons is usually higher than that of the Baltic Sea. In the future, the sea level of the Baltic Sea is projected to rise, resulting in a possible widening and deepening of connecting inlets. Thus, the water exchange between lagoons and the Baltic Proper will increase, leading to a decrease in the difference in sea-level heights and an increase in salinity in the lagoons. 


\subsection{Salinity dynamics of the Gulf of Finland}

The Gulf of Finland is an elongated sub-basin of the Baltic Sea located in the north-eastern extremity of the sea (Fig. 1). The length of the Gulf is about $400 \mathrm{~km}$, and its width vary between 48 and $135 \mathrm{~km}$ (Myrberg, 1998). The mean depth of the Gulf is $37 \mathrm{~m}$, the maximum depth being $123 \mathrm{~m}$ (in the Baltic Sea $459 \mathrm{~m}$ ). The drainage area of $420990 \mathrm{~km}^{2}$ is $20 \%$ of the total drainage area of the entire Baltic Sea. The water budget in the gulf is mainly determined by unrestricted and continuous water exchange with the Northern Baltic Proper in the west and river discharge, which is mainly concentrated in the eastern part, where the largest river of the entire Baltic Sea locates; namely the river Neva. The water column can be divided into three layers - the upper mixed layer, the cold intermediate layer , and the sub-halocline near-bottom layer separated by the seasonal thermocline and the quasi-permanent halocline, respectively (Alenius et al., 1998, 2003; Soomere et al., 2008). The seasonal thermocline vanishes on a yearly basis, during autumn-winter. Strong wind events, reversing the estuarine circulation (Elken et al., 2003), can occasionally destroy the halocline for more than a month in large areas of the gulf in winter (Liblik et al., 2013). Surface salinity increases from about $1 \mathrm{~g} \mathrm{~kg}^{-1}$ in the easternmost part to $6 \mathrm{~g} \mathrm{~kg}^{-1}$ in the western part. On average, surface salinity is higher near the southern coast than the northern coast (Kikas and Lips, 2016; Liblik and Lips, 2017) due to the general cyclonic circulation scheme (Andrejev et al., 2004a, b). The westward flowing current along the northern coast is changing its location across the gulf mainly due to wind forcing (Kikas and Lips, 2016; Liblik and Lips, 2017; Lips et al., 2016a).

Wind-driven processes, such as the along-gulf advection, coupled up- and downwelling events, and vertical mixing, play an important role in the salinity dynamics. Westerly winds bring the saltier upper layer water to the gulf from the Baltic Proper (Lilover et al., 2016; Suhhova et al., 2018), weaken the stratification and deepen the upper mixed layer (Liblik and Lips, 2017). Easterly winds have an opposite effect; these intensify the transport of fresher waters to the west (Elken et al., 2003; Liblik and Lips, 2012), shallow the mixed layer and strengthen the haline stratification (Liblik and Lips, 2017). The latter process can lead to the formation of the shallow haline stratification in winter (Liblik et al., 2013). Shallowing or deepening of the upper mixed layer due to the prevailing winds can be an important factor influencing the primary production and species dominance during the summer cyanobacteria blooms (Kanoshina et al., 2003).

Coupled up- and downwelling events bring denser water from the cold intermediate layer to the surface layer, where it mixes with the ambient upper layer water (Myrberg and Andrejev, 2003, Lips et al., 2009). Upwelling-downwelling events in the southern/northern coast have several distinctive characteristics. Less wind forcing is needed to generate upwelling along the southern coast than the northern coast (Kikas and Lips, 2016; Liblik and Lips, 2017). Stronger lateral salinity, temperature and density gradients occur in the upper layer in the case of upwelling along the southern coast (Kikas and Lips, 2016; Liblik and Lips, 2017). Eastward advection in the surface layer and downwelling along the southern coast generated by westerly winds can form a thick upper mixed layer ( $>45 \mathrm{~m}$ ) in summer (Liblik and Lips, 2017). A positive trend in the upwelling occurrence along the northern coast was detected in 1990-2009 (Lehmann et al., 2012). However, no long-term trends were seen in the upwelling favorable winds in 1982-2013 (Liblik and Lips, 2017). 
First, in situ measurements and modeling experiments have been conducted to characterize sub-mesoscale processes and their impact on the development of stratification and vertical mixing in the gulf (Lips et al., 2016a; Väli et al., 2013; Vankevich et al., 2016).

The gulf is impacted by estuarine circulation reversals caused by westerly wind impulses (Elken et al., 2003), which considerably weaken the halocline and lower salinity in deep layers (Elken et al., 2003; Lilover et al., 2016; Stoicescu et al., 2019). In the case of long-lasting, strong westerly winds, circulation reversals can lead to the vanishing of the stratification in large areas of the gulf in winter (Liblik et al., 2013; Lips et al., 2017). Stratification collapse events have become more frequent since the 1990s (Elken et al., 2014). More frequent and stronger westerly winds during winters (Keevallik and Soomere, 2014) generate more reversals and likely cause salinity minimum in the annual cycle of the deep layer (Lehtoranta et al., 2017; Maljutenko and Raudsepp, 2019). The reversals, together with upward salt flux created by convective and wind mixing, cause a maximum in the annual cycle of the upper layer salinity in the winter period. Salinity maximum/minimum usually occurs in the deep/surface layer in summer, when the seasonal thermocline restricts vertical mixing, and westerly winds are not that dominant. Another minimum in the sea surface salinity might occur due to a lack of vertical mixing in the ice-covered areas in late winter (Merkouriadi and Leppäranta, 2015).

Multi-year changes of salinity in the deep layer depend on the occurrence of MBIs (Laine et al., 2007; Liblik et al., 2018;

375 Liblik and Lips, 2011). If the water exchange with the North Sea was artificially limited in a numerical experiment, salinity decreased in the deep layer of the gulf (Lessin et al., 2014). After the recent MBIs (Naumann et al., 2018), salinity peaked at $10.77 \mathrm{~g} \mathrm{~kg}^{-1}$ in the near-bottom layer of the central gulf (Liblik et al., 2018), which is the highest value since 1974 (Alenius et al., 1998). Former deep layer water from the Northern Baltic Proper was pushed to the gulf nine months after (Liblik et al., 2018) the MBI occurred in December 2014 (Mohrholz et al., 2015). The MBI water, which originates from the depths of

380 110-120 $\mathrm{m}$ in the Eastern Gotland Basin (compare with Fig. 2), arrived in the gulf 14-15 months after the inflow (Liblik et al., 2018).

Decadal trends of salinity show vertically distinct changes. Surface salinity decrease since the early 1980s has been estimated to be in the range from $0.005 \mathrm{~g} \mathrm{~kg}^{-1}$ (Liblik and Lips, 2019) to $0.02 \mathrm{~g} \mathrm{~kg}^{-1}$ per year (Almén et al., 2017). Long-term records close to the island of Utö revealed a sea surface salinity decrease from the early 1980s to mid-1990s (Laakso et al., 2018; compare with Fig. 2 and Fig. 4). However, the surface salinity increased by $0.5 \mathrm{~g} \mathrm{~kg}^{-1}$ during 1927-2012 in the northwestern part of the gulf (Merkouriadi and Leppäranta, 2014). The salinity trend in the deep layer of the central gulf has been estimated to be $0.04 \mathrm{~g} \mathrm{~kg}^{-1}$ per year from 1982-2016 (Liblik and Lips, 2019).

\subsection{Salinity dynamics of the Gulf of Bothnia}

390 The mean depth of the Gulf of Bothnia is 55 metres, and its surface area is $30 \%$ of the entire Baltic Sea. The Gulf of Bothnia is mainly separated from the northern Baltic Proper by sills and archipelagos. Its hydrography is quite different from other parts of the Baltic Sea (Fig. 1). The sill between Åland Sea and Baltic Proper prevents the northward propagation of deep- 
water flow. It is assumed that the water masses in the Bothnian Sea are renewed mainly by inflowing surface water from the Baltic Proper (Marmefelt and Omstedt, 1993, Meier, 2007). The net water exchange through the Archipelago Sea is estimated to be low compared to the Åland Sea (Omstedt et al., 2004, Myrberg and Andrejev, 2006, Tuomi et al., 2018). In the Gulf of Bothnia, the salinity stratification is weak. The surface salinity in the Åland Sea is about $5.25-6.25 \mathrm{~g} \mathrm{~kg}^{-1}$ whereas at a depth of 200 meters, salinity varies between 7 and $7.75 \mathrm{~g} \mathrm{~kg}^{-1}$. Deep salinity in the Åland Sea and the Sea of Bothnia stems from the upper homohaline layer of the Northern Baltic Proper. Additionally, a small fraction of more saline deep-water flows in over sills. The inflow of saline water through the Åland Sea over the sills can cause a corresponding flow of fresher water out into the Gotland Basin. This strengthens the stratification in the Sea of Bothnia (Leppäranta and Myrberg, 2009).

In the Sea of Bothnia (Fig. 1), the surface salinity varies between 4.8 and $6.0 \mathrm{~g} \mathrm{~kg}^{-1}$ and in the lower layer at $150 \mathrm{~m}$ depth, the salinity is 6.4-7.2 $\mathrm{g} \mathrm{kg}^{-1}$. In the Bay of Bothnia (Fig. 1), the salinity is between 2 and $3.8 \mathrm{~g} \mathrm{~kg}^{-1}$ and at $100 \mathrm{~m}$ depth near the bottom it varies between 4 and $4.5 \mathrm{~g} \mathrm{~kg}^{-1}$. The Gulf of Bothnia has many rivers, and near the river mouths, the salinity is close to zero. Even in the Sea of Bothnia, the salinity stratification is relatively weak, and overall oxygen conditions have remained fairly good, not to mention some specific coastal areas. However, oxygen conditions in the deepest layer have somewhat deteriorated over the recent two decades, although there is no real evidence that hypoxic conditions will occur in future (Raateoja et al., 2013).

\section{Climate variability and change - impact on salinity dynamics}

\subsection{Development of the mean salinity}

The long-term changes in the salinity of the Baltic Sea depend to a large extent on net precipitation, river discharge and wind forcing (Winsor et al. 2001, 2003; Meier and Kauker 2003; Gustafsson and Omstedt, 2009); higher salinity appears during dry and lower salinity during wet periods. Furthermore, on shorter timescales, the mean salinity of the Baltic Sea is governed by the water exchange between the North Sea and the Baltic Sea, which by itself is governed by the prevailing atmospheric conditions. Generally, westerly winds force the inflow of saline water and easterly winds force outflow of brackish Baltic Sea water. Multi-decadal oscillations control the long-term variations of the surface salinity and its meridional gradient with a period of about 30 years (Radtke et al. 2020). A statistically significant positive trend of centennial changes of the northsouth gradient of the surface salinity has been found (Kniebusch et al., 2019). Increased river runoff from the most northern catchment could explain this trend. Observations reveal (Fig. 5, see chapter 5.1) that after the minimum around 2003/2004, the volume-averaged salinity increased again until 2018. Fluctuation in the accumulated anomalies of river runoff coincides with the variability in mean salinity, confirming the role of river runoff in controlling the mean salinity of the Baltic Sea (Kniebusch et al., 2019; Radtke et al. 2020). 


\subsection{Internal circulation and stratification}

425 The long-term salinity dynamics within the Baltic Sea is controlled by the large-scale internal water cycle (e.g. Elken and Matthäus, 2008). There is a surface layer circulation and a deep-water circulation decoupled in the Baltic Proper by the permanent halocline. The wind and freshwater surplus drive the upper layer circulation. It is mainly of Ekman dynamics in combination with complex coastlines and up- and downwelling. In the lower layer, the flow, dense bottom current, is driven by internal pressure gradients steered by the complex bottom topography consisting of deep basins and channels and restricted by sills (Leppäranta and Myrberg, 2009). The vertical branch of this circulation system, termed the Baltic Sea haline conveyer belt (Döös et al., 2004), is restricted by the strong permanent saline stratification. Convection, mechanical mixing, entrainment and vertical advection determine the vertical salt flux across the halocline. It is not only the mean salinity of the Baltic Sea which is varying over the years, there are also considerable changes in the strength of the permanent salinity stratification. Liblik and Lips (2019) found a strengthening of the permanent halocline in the deep basins of the Baltic Sea over the period 1982-2016. They argued that the accumulated river runoff probably caused the decrease in surface salinity. However, they found no correspondence between increased runoff and decreased surface salinity in the second half of the period (compare Fig. 4 and 5). They argued that changes in the vertical salt transport might be the reason for this, which might be related to changes in meteorological forcing. However, the volume-averaged salinity of the eastern Gotland Basin is highly correlated with the accumulated river runoff (Fig. 5). After the Major Inflow in January 1993, 440 salinity increased in the lower layer of the eastern Gotland Basin (Fig. 2). This increasing trend of deep layer salinity (Fig. 3) due to stronger lateral salt transport from the Kattegat could not be explained by a growing number of barotropic and Major Baltic Inflows (Mohrholz, 2018). So, the reason for the change of the haline stratification in the deep basins of the Baltic Sea over the recent three decades remains unclear.

\subsubsection{The specific role of precipitation and river runoff}

445 River runoff (R) and net precipitation (P-E) over the sea surface are dominant drivers of the Baltic Sea salinity, explaining together with the limited water exchange with the North Sea the large gradient in sea surface salinity between about $20 \mathrm{~g} \mathrm{~kg}^{-1}$ in Kattegat and $2 \mathrm{~g} \mathrm{~kg}^{-1}$ in the Bothnian Bay (Leppäranta and Myrberg, 2009). Net precipitation amounts to about $10 \%$ of the total river runoff (e.g., Leppäranta and Myrberg, 2009, Meier and Döscher, 2002), even if there are some uncertainties in these estimations. For the period 1850-2008, the total river runoff from the Baltic Sea catchment area reconstructed from observations (Hansson et al., 2011; Cyberski and Wroblewski, 2000; Mikulski, 1986; Bergström and Carlsson, 1994) and hydrological model results (Graham, 1999) show no statistically significant trend but a pronounced multi-decadal variability with a period of about 30 years (Meier et al., 2019a, Meier et al., 2019b). According to model results, these variations in runoff explained about $50 \%$ of the long-term variability of the volume-averaged salinity of the Baltic Sea (Meier and Kauker, 2003). This relationship is also confirmed for the period 1979 to 2018 presented in Fig. 5. The volume-averaged salinity of the eastern Gotland Basin is highly negatively correlated with the accumulated anomaly of runoff to the Baltic 
Sea. About $27 \%$ of the interannual salinity variation is explained by the direct dilution effect (Radtke et al. 2020). In addition to the 30 years period (Meier et al., 2018), there is a pronounced decadal variability of both mean salinity and accumulated anomaly of runoff with the minima of mean salinity directly associated with the maxima in runoff anomaly. Furthermore, minima of mean salinities occur just before major saltwater inflows (MBIs) happen. Since about the 1970s, the mean seasonal cycle of the total river flow has changed with increasing and decreasing runoff during winter and summer (Meier and Kauker, 2003). These changes might be explained by river regulation of large rivers in the North and systematic changes in precipitation patterns due to warming in the Baltic Sea region. However, the change in seasonality does not affect the total discharge trend. As there is no statistically significant trend in saltwater inflows on the centennial time scale (Mohrholz, 2018), changes in salinity are regionally limited. Furthermore, there is neither any statistically significant long-term trend in salinity (Fonselius and Valderrama, 2013). As a consequence of the pronounced 30-year variability in runoff and MBIs, the mean salinity shows these variations as well (Winsor et al., 2001; 2003). As part of the variability, during 1983-1993, a stagnation period without MBI and with decreasing salinity was observed (Nehring and Matthäus, 1991). Model results suggest that decreasing salinity over about 10 years appear approximately once per century on average and belongs to the natural variability of the system (Schimanke and Meier, 2016).

470 On longer time scales, the Baltic Sea salinity is under the influence of the AMO with a period of about 60-90 years (Börgel et al., 2018). Since about the 1980s, increased bottom and decreased surface salinities have been observed (Vuorinen et al., 2015; Liblik and Lips, 2019), and an accelerated warming might be attributed to the AMO (Kniebusch et al., 2019). Whether the recent salinity changes are connected with the AMO is still unknown.

Besides local effects on surface salinity, due to varying river runoff and net precipitation, there is an additional remote effect due to the accumulated volume of freshwater. This water volume has to leave the Baltic Sea as a brackish surface outflow through the Danish Straits. Periods of positive anomalies of freshwater input (P-E+R) lead to increasing outflow and a shift of the wedge-shape salinity fronts in the Belt Sea and the Sound further in direction to the Kattegat, indirectly impacting the compensating inflow of higher saline water over the Drodgen and Darss Sills. During negative anomalies of freshwater input, reduced outflow occurs, and the wedge shape salinity front moves further in the direction to the Darss and Drodgen Sills (Lehmann and Hinrichsen, 2000). As the net precipitation is in the order of $10 \%$ of the total river runoff, wet years will lead to a decreased salt flux into the Baltic Sea, and dry years will lead to an increased salt flux.

\subsubsection{The role of sea level change due to global warming}

Especially, the northern areas experience an acceleration of global warming during recent decades. The linear trend of global temperature increase shows warming of $0.85^{\circ} \mathrm{C}$ over 1880 to 2012 (IPCC, 2019). The linear temperature rise for the Baltic 485 Sea is about $0.4^{\circ} \mathrm{C}$ per decade (e.g. Lehmann et al., 2011).

The absolute sea level rise of the Baltic Sea over the twentieth century is about $1.3-1.8 \mathrm{~mm}$ per year, within the range of global estimates. In more recent decades, the basin-wide range of sea level rise may be around $5 \mathrm{~mm}$ per year with a rather 
considerable uncertainty of $\pm 3 \mathrm{~mm}$ per year, even higher than the global mean sea level (GMSL) estimate of $3.2 \mathrm{~mm}$ per year (Hünicke et al. 2015, Dangendorf, 2019).

Hordoir et al. (2015) investigated the influence of rising GMSL on saltwater inflows into the Baltic Sea. They performed idealized model sensitivity experiments using a regional ocean general circulation model covering the North Sea and the Baltic Sea. Hordoir et al. (2015) found a non-linear increase in saltwater inflow intensity and frequency with rising GMSL. However, their explanation of reduced mixing in the Danish Straits was shown to be wrong (Arneborg, 2016). Arneborg (2016) proposed an alternative theory instead. Due to the smaller depth, the volume flux through the Sound is more sensitive to GMSL rise than that through the Belt Sea. Under present conditions, the amount of dense water passing the Drogden Sill in the Sound is determined by a baroclinic control in the narrow northern end of the Sound (Nielsen, 2001). With rising GMSL, this control is degraded, and relatively more saltwater is transported into the Baltic Sea compared to the expected increase when the transport change is proportional to the area of the limiting cross-section. Assuming a negligible impact of GMSL rise, the intensity and frequency of MBIs were projected to remain unchanged, with a potential tendency of a slight increase (Schimanke et al., 2014). However, in future high-end global mean sea level projections, reinforced saltwater inflows result in higher salinity and increased vertical stratification than present conditions (Meier et al., 2017; Saraiva et al., 2019b).

\section{The impact of salinity dynamics on the environmental conditions of the marine ecosystem}

\subsection{Oxygen conditions}

Generally, the Baltic Sea's oxygen distribution results from the input through the atmosphere-ocean interface, physical transport, and the consumption of oxygen due to respiration and biogeochemical processes. The layer above the halocline is well oxygenated due to vertical convection during winter. In and below the halocline, the ventilation is happening only by horizontal advection of water originating from the Danish Straits and the Kattegat. In the deep basins below the halocline,

510 there is often no sufficient oxygen supply so that continuous oxygen consumption leads to hypoxic or even anoxic conditions. In the Bothnian Sea and Bothnian Bay (Fig. 1), the salinity stratification is weak, so that vertical deep convection during winter prevents these basins from oxygen deficiency so far.

Climate warming impacts not only the deep-water oxygen distribution. The solubility of oxygen at the surface depends on the water temperature. In warmer water, the solubility is reduced and, oxygen consumption is increased by enhanced 515 decomposition of organic matter. Thus, even after major saltwater inflows, MBIs, which can reach the deep basins of the Baltic Sea, improved oxygen conditions will faster turn back to hypoxic conditions than former times (Naumann et al. 2018). The trend in oxygen depletion is about $0.1 \mathrm{ml} \mathrm{l}^{-1}$ per decade in the surface layer and up to $1 \mathrm{ml} \mathrm{l}^{-1}$ per decade in the halocline (Fig. 3). 


\subsection{Environmental interaction between fish/larvae and salinity dynamics}

Roughly 100 fish species occur in the Baltic Sea. Their spatial distribution is primarily governed directly by salinity and oxygen. Marine species ( 70 species) dominate in the central Baltic Sea, while freshwater species (30-40 species) mainly occur in coastal areas and the north-eastern parts of the Baltic Sea (HELCOM, 2002). Cod, herring and sprat comprise most of the fish community in biomass and numbers. Commercially important are the marine species sprat, herring, cod, various flatfish, salmon, and the freshwater species pike and perch before severe stock declines (Nilsson et al., 2004).

Cod eggs in the Baltic Sea have a vertical distribution concentrated in deep water and near or below the permanent halocline (Wieland and Jarre-Teichmann, 1997). Thus, cod eggs are frequently distributed in water layers with very low oxygen concentration (Nissling et al., 1994; Wieland et al., 1994). The eastern Baltic cod has a prolonged spawning period from March to September (Köster et al., 2017). The reproductive layer thickness for Eastern Baltic cod is limited to minimum environmental threshold values (salinity $=11 \mathrm{~g} \mathrm{~kg}^{-1}$, temperature $=1.5{ }^{\circ} \mathrm{C}$, and oxygen $2 \mathrm{ml} \mathrm{l}^{-1}$; Wieland and JarreTeichmann, 1997; Westin and Nissling, 1991; Nissling et al., 1994; Wieland et al., 1994). The reproductive layer thickness for western Baltic cod in February/March (the peak spawning time of this stock) is limited to minimum environmental threshold values (salinity $=16.5 \mathrm{~g} \mathrm{~kg}^{-1}$, temperature $=2^{\circ} \mathrm{C}$, and oxygen $=2 \mathrm{ml} \mathrm{l}^{-1}$; Nissling and Westin, 1997) to keep western eggs in the Arkona Basin floating to allow successful development and survival. In a modeling study, Hinrichsen et al. (2016a) showed that the spatial extent of the habitat suitable for successful fertilization and development of eggs of the eastern cod stock is primarily determined by oxygen and salinity conditions at spawning. The highest survival of Eastern Baltic cod eggs occurred in the Bornholm Basin and a pronounced temporal decrease of survival in the Gdansk Deep and the Gotland Basin. Relatively low survival in these areas was attributable to oxygen-dependent mortality. Compared to eggs spawned in these eastern spawning grounds, eggs spawned in the Arkona Basin were affected mainly by sedimentation, i.e. the lack of sufficiently saline water at the bottom to ensure successful egg fertilization and development. However, since the mid-2000s, a substantial increase in sedimentation-related mortality has also been observed for the Gdansk Deep (Hinrichsen et al., 2016a).

For the Bornholm Basin, Hinrichsen et al. (2016b) estimated the geographic extent of the area with hydrographic conditions suitable for egg development in early (April-May), mid (June-July) and late (August-September) spawning season. Egg

545 survival depends on their buoyancy which is related to female age and/or size. Large eggs, for example, are spawned by large, old females and float at low water density. The seasonal timing of spawning does not matter for these large eggs, while for small eggs spawned by young females sink towards the bottom and suffer higher mortality due to exposure to hypoxic conditions. The geographic area suitable for their survival is concurrently lower than for larger eggs, with most favorable conditions occurring late in the spawning season owing to the summer inflows.

550 The Arkona Basin, a relatively shallow area (max depth $\sim 40 \mathrm{~m}$ ) mainly occupied by the western Baltic cod stock, has presently also been utilized as spawning ground by the Eastern cod stock (Bleil et al., 2009; Hüssy, 2011). Generally, the 
reproductive conditions appear to be more favorable for the eastern stock, with several occasions of relatively large reproductive layer thicknesses since 1999, which was extremely seldom observed for the western stock. Vertical resolution data of the reproductive layer thickness for both stocks showed improved reproductive conditions for eastern cod of about 10 m overall layer thicknesses in June to August since 2000. A certain fraction of the egg production of the Eastern cod stock can be expected to sink to the bottom and die. However, in a combined stock identification and drift model study, Hüssy et al. (2015) showed that Eastern Baltic cod progressively immigrated into the Arkona Basin during recent years. This resulted in stock mixing with the western stock, showing a marked increase in proportion between 2005 and 2008 with a fairly stable proportion of approximately $70-80 \%$ since then. Even though this stock mixing is purely a physical admixture without interbreeding (Hemmer Hansen et al., 2019), the immigrating eastern cod may have contributed to the recruitment of the eastern cod stock in this management area. However, this was only possible for relatively late spawning eastern cod and in years characterized by specific conditions, i.e. after summer inflows of saline water.

\section{Present knowledge gaps}

565 There is still a need to understand better the role of freshwater balance on salinity distribution and its variability on seasonal to inter-annual time scales. The surface salinity of the eastern Gotland Basin varied over the recent four decades (Fig. 4). In the 1970s, it started at relatively high values of about $7.5 \mathrm{~g} \mathrm{~kg}^{-1}$, decreased until 2002 and slightly increased until 2018. There is a pronounced interannual variability of the surface salinity, which might be related to changes in the atmospheric forcing (wind and precipitation over the sea) and/or river runoff (Radtke et al. 2020). There is still research needed to understand better the development of salinity stratification and its role in increasing hypoxia and to evaluate the changes in atmospheric circulation and its impact on inflows and salinity distribution in the Baltic Sea. One key question is the complete mechanistic description of barotropic and major saltwater inflows, MBIs. Even if these have been studied for decades, we can question whether we really understand the process, can we predict MBIs? Extended outflow periods before the inflow reduce the mean sea level of the Baltic Sea, and in parallel lead to the formation of a haline stratification in the Danish Straits with the highly saline water propagating to the direction of Darss and Drodgen Sills. The frequency of low-pressure systems passing over the Baltic Sea and the strength of the wind will be enhanced for MBIs compared to LVCs. Thus, this leads to higher transport rates.

Forthcoming work needs to explore the chain of processes in detail, which additionally to large barotropic inflows leads to an influx of highly saline and oxygenated water. The freshwater input seems to play only a modulating role for the 580 occurrence and strength of barotropic inflows. The total frequency of inflow events will not change, but the average amount of salt which an individual event transports into the Baltic Sea (Radtke et a. 2020). Both river runoff and the strength of barotropic inflow show a variation on a 30-year timescale, and both show a stable and plausible phase relationship to be the driver of interdecadal salinity variations (Radtke et al., 2020). 
Summer inflows of saline water masses can be traced in the Bornholm Basin by unusually high temperatures in the halocline

zone. Warm and salty summer inflows belong to baroclinic inflows. They might result in higher connectivity between nursery areas of pelagic fish species west of their principal spawning grounds and spawning stocks, e.g. for Baltic cod and flounder (Ruzzante et al., 2006; Svedäng et al., 2007).

At the time, detailed studies on summer inflows and how they might have changed over time are missing. There are also local processes that deserve further studies. Detailed assessments of the exchange between coastal areas, including lagoons and open sea, and between sub-basins, the cold intermediate layer and turbulent mixing are unavailable. To improve our knowledge of these processes, we need detailed and joint modeling and observational studies.

One very topical issue, which is indirectly linked to salinity distributions, is the general circulation of the Baltic Sea. Do we understand all branches of the Baltic Sea haline conveyer belt? There are few regular observations of it, and the modeling exercises show significant discrepancies between their results and observations.

\section{Key messages}

The long-term salinity dynamics is controlled by river runoff, net precipitation and the governing east-west wind conditions, i.e. the water mass exchange between the North Sea and the Baltic Sea. There is no clear long-term trend of the mean salinity of the Baltic Sea, even if, during the last 40 years, surface salinity has decreased, and the lower layer salinity increased. This might be connected to changes in the vertical flux of salinity, but the explanation is still unclear. Changes in runoff are highly correlated with the development of the mean salinity of the Baltic Sea and explain about $50 \%$ of its variability (Fig. 5). A 30-year variability has been found for surface and bottom salinity, river runoff and salt transport across the Darss Sill. Variations of salinity on shorter time scales (monthly to annual) are even more complex, especially in and below the halocline. Furthermore, there is a direct effect on temperature and salinity distributions. Stronger saltwater inflows can directly be traced by changes in the deep-water salinity and corresponding changes in temperature and oxygen (Fig. 2).

Over recent decades, negative salinity trends appear at the surface. At the same time, temperature increases, and oxygen decreases. The linear trend $\left(\sim 0.4{ }^{\circ} \mathrm{C} /\right.$ decade $)$ of the sea surface temperature of the Baltic Sea is about the same as the air temperature trend.

The decreasing trend in oxygen can partly be explained by increasing temperatures which affect oxygen solubility and depletion rates. Maximum negative trends up to $1 \mathrm{ml} \mathrm{l}^{-1}$ per decade can be found in the halocline of Bornholm and Gotland Basin (Fig. 3).

The major saltwater inflow in December 2014 stimulated new research to revisit the barotropic water exchange between Kattegat and the Baltic Sea. 
The major saltwater inflows, MBIs, which occur in response to specific atmospheric circulation patterns, can be regarded as 615 a subset of barotropic inflows or Large Volume Changes. Atmospheric forcing is more strongly associated with LVCs than MBIs, while it directly controls the sea level and indirectly the amount of salt of the inflowing water mass.

The strength of the inflows and the amount of salt transported into the Baltic Sea depend on the intensity of the wind and the haline stratification in the Danish Straits.

620 It has been widely speculated that MBIs play the most crucial role in the development of deepwater salinity. Still, recent studies show that the frequency of major saltwater inflows did not change. So, the associated worsening of bottom oxygen conditions is caused by excessive nutrient loading and related oxygen consumption and maybe due to increased stratification. This strongly suggests that reducing the external nutrient load to the Baltic Sea is still highly needed to improve its ecological state.

625 At regional scales, in addition to the interaction with the main Baltic Sea, the salinity regime of estuaries and lagoons is closely related to the local water balance components, including river runoff, precipitation, and evaporation. So, in the changing climatic conditions, the development of the salinity regime at regional scales may have various basic-specific features that might be diverse from corresponding trends in the main Baltic Sea. This fact will raise a high demand to carry out basin-specific studies to understand the changes in the local salinity regime.

630 Finally, we can summarize our present knowledge of salinity dynamics as follows. There is now a better overall view of the salinity of the Baltic Sea than before: not only the fragments in various scales of time and space are known. The measurements have given an improved view also in the regional scale, in gulfs and lagoons, not only in the central part of the sea, or some volume-averaged case. Future projections are existing, but they still have lot of uncertainties. The temporal variability can now been divided between the decadal and smaller scales.

\section{Author contribution}

Andreas Lehmann wrote the main parts of the manuscript and prepared the manuscript with contributions from all coauthors. Kai Myrberg contributed to the main parts of the manuscript. Piia Post also contributed to the overall manuscript and wrote the main parts of chapter 3. Irina Chubarenko contributed to chapter 4. Inga Dailidiene contributed to chapter 5.

640 Hans-Harald Hinrichsen contributed to chapter 7. Karin Hüssi also contributed to chapter 7. Taavi Liblik commented on the entire draft manuscript and contributed to the main parts of chapter 4 and 5. Urmas Lips also contributed to the main parts of chapter 4 and 5. Markus Meier commented on the entire manuscript and contributed to chapter 6, and Tatiana Bukanova contributed to chapter 4 . 


\section{Code availability}

Not applicable.

\section{Data availability}

Not applicable.

\section{Competing interests}

The authors declare that they have no conflict of interest.

\section{Acknowledgements}

This work has been initiated and accompanied by Baltic Earth. We are incredibly grateful for the support of the Baltic Earth 655 secretariat.

\section{References}

Alenius, P., Myrberg, K., and Nekrasov, A.: The physical oceanography of the Gulf of Finland: a review. Boreal Env. Res 3, 97-125. Available at: http://www.borenv.net/BER/pdfs/ber3/ber3-097-125.pdf, 1998.

Alenius, P., Nekrasov, A., and Myrberg, K.: Variability of the baroclinic Rossby radius in the Gulf of Finland. Cont. Shelf 660 Res. 23, 563-573. doi:10.1016/S0278-4343(03)00004-9, 2003.

Almén, A.-K., Glippa, O., Pettersson, H., Alenius, P., and Engström-Öst, J.: Changes in wintertime pH and hydrography of the Gulf of Finland (Baltic Sea) with focus on depth layers. Environ. Monit. Assess. 189, 147. doi:10.1007/s10661-0175840-7, 2017.

Andrejev, O., Myrberg, K., Alenius, P., and Lundberg, P. A.: Mean circulation and water exchange in the Gulf of Finland-a 665 study based on three-dimensional modelling. Available at: http://www.borenv.net/BER/pdfs/ber9/ber9-001.pdf [Accessed November 22, 2018], 2004a.

Andrejev, O., Myrberg, K. and Lundberg, P. A.: Age and renewal time of water masses in a semi-enclosed basinApplication to the Gulf of Finland. Tellus 56A, 548-558, 2004b. 
Arneborg, L.: Comment on "Influence of sea level rise on the dynamics of salt inflows in the Baltic Sea" by R. Hordoir, L.

Axell, U. Löptien, H. Dietze, and I. Kuznetsov. Journal of Geophysical Research: Oceans 121(3), 2035-2040. https://doi.org/ 10.1002/2015JC011451, 2016.

BACC I Author Team: Assessment of Climate Change for the Baltic Sea Basin. Berlin- Heidelberg: Springer-Verlag, 2008.

BACC II Author Team: Second assessment of climate change for the Baltic Sea Basin. Regional Climate Studies. Cham: Springer. https://doi.org/10.1007/978-3-319-16006-1, 2015.

Barry, R.G. and Carleton, A.M.: Synoptic and dynamic climatology. Routledge, 619 pp., 2013.

Bergström S, Carlsson B.: River runoff to the Baltic Sea: 1950-1990. AMBIO 23:280-287, 1994.

Berzinsh, V. : "Hydrology,” in Ecosystem of the Gulf of Riga Between 1920 and 1990, ed. E. Ojaveer (Tallinn: Estonian Acad. Publ.), 7-31, 1995.

Bleil, M., Oeberst, R., and Urrutia, P.: Seasonal maturity development of Baltic cod in differentspawning areas: importance of the Arkona Sea for the summer spawning stock. Journal of Applied Ichthyology, 25: 10-17, 2009.

Börgel, F., C. Frauen, T. Neumann, S. Schimanke, and H. E. M. Meier, 2018: Impact of the Atlantic Multidecadal Oscillation on Baltic Sea variability. Geophysical Research Letter, 45(18), 9880-9888, https://doi.org/10h.1029/2018GL078943, 2018.

Cassou, C., Terray, L., Hurrell, J. W., \& Deser, C.: North Atlantic Winter Climate Regimes: Spatial Asymmetry, Stationarity 685 with Time, and Oceanic Forcing, Journal of Climate, 17(5), 1055-1068, 2004.

Chubarenko, I.P., Demchenko, N.Yu., Esiukova, E.E., et al.: Formation of spring thermocline in coastal zone of the SouthEastern Baltic Sea on the base of field measurement data 2010-2013. Oceanology 57(5), 632-638. doi: 10.1134/S000143701705006X, 2017.

Chubarenko I. and Stepanova N.: Cold Intermediate Layer of the Baltic Sea: hypothesis of the formation of its core. Progress in Oceanography. Vol. 167, October 2018, pp. 1-10. https://doi.org/10.1016/j.pocean.2018.06.012, 2018.

Cyberski J. and Wroblewski A .:Riverine water inflows and the Baltic Sea water volume 1901-1990. Hydrol Earth Syst Sci 4:1-11, 2000.

Dailidiene, I., Baudler, H., Chubarenko, B., Navrotskaya, S.: Long term water level and surface temperature changes in the lagoons of the southern and eastern Baltic. Oceanologia, 53, 293 - 308, 2011.

695 Dangendorf, S., Hay, C., Calafat, F.M., Marcos, M., Piecuch, C.G., Berk, K. and Jensen, J.: Persistent acceleration in global sea -level rise since the 1960s. Nature Climate Change, 9, 705 -710, 2019.

Döös, K., Meier, H.E.M. and Döscher, R.: The Baltic haline conveyor belt or the overturning circulation and mixing in the Baltic. Ambio 33, 261-266, 2004.

Eilola, K. and Stigebrandt, A.: Spreading of juvenile freshwater in the Baltic Proper. J. Geophys. Res. 103, 27795-27807, 7001998.

Elken, J. and Matthäus, W.: Physical system description. In: The BACC Author Team (ed.). Assessment of climate change for the Baltic Sea Basin. Springer-Verlag, Berlin, Heidelberg, p 379 - 386, 2008. 
Elken, J., Raudsepp, U., Laanemets, J., Passenko, J., Maljutenko, I., Pärn, O., et al.: Increased frequency of wintertime stratification collapse events in the Gulf of Finland since the 1990s. J. Mar. Syst. 129, 47-55. doi:10.1016/j.jmarsys.2013.04.015, 2014.

Elken, J., Raudsepp, U., and Lips, U.: On the estuarine transport reversal in deep layers of the Gulf of Finland. J. Sea Res. 49, 267-274. doi:10.1016/S1385-1101(03)00018-2, 2003.

Elken, J., Lehmann, A., and Myrberg, K.: Recent Change-Marine Circulation and Stratification. In Second Assessment of Climate Change for the Baltic Sea Basin, pp. 131-144. Ed. by BACC II Author team. Springer, Springer Cham, Heidelberg, 710 New York, Dordrecht, London, 501 pp., 2015.

Feser, F., Barcikowska, M., Krueger, O., Schenk, F., Weisse, R. and Xia, L., 2015. Storminess over the North Atlantic and northwestern Europe-A review. Quarterly Journal of the Royal Meteorological Society, 141(687), 350-382, 2015.

Fischer, H. and Matthäus, W.: The importance of the Drogden Sill in the Sound for major Baltic inflows. Journal of Marine Systems, 9, 137-157, 1996.

715 Fonselius, S., and Valderrama, J.: One hundred years of hydrographic measurements in the Baltic Sea. Journal of Sea Research, 49(4), 229-241, 2003.

Friedland R., Schernewski G., Gräwe U., Greipsland I., Palazzo D. and Pastuszak M.: Managing Eutrophication in the Szczecin (Oder) Lagoon-Development, Present State and Future Perspectives. Front. Mar. Sci. 5:521. doi: 10.3389/fmars.2018.00521, 2019.

720 Giesse, C., Meier, H.E, M., Neumann, T. and Moros, M.: Revisiting the Role of Convective Deep Water Formation in Northern Baltic Sea Bottom Water Renewal. J. Geophys. Res. Oceans, https://doi.org/10.1029/2020JC016114, 2020.

Gräwe, U., Naumann, M., Mohrholz, V. and Burchard, H.: Anatomizing one of the largest saltwater inflows into the Baltic Sea in December 2014. Journal of Geophysical Research, Oceans, https://doi.org/10.1002/2015JC011269, 2015.

Graham L.P. : Modeling runoff to the Baltic Sea. AMBIO 27:328-334, 1999.

725 Gustafsson, E. and Omstedt, A.: Sensitivity of Baltic Sea deep water salinity and oxygen concentration to variations in physical forcing. Boreal Environ. Res.14:18 - 30, 2009.

Hansson D.C., Eriksson C., Omstedt A. and Chen D.:Reconstruction of river runoff to the Baltic Sea, AD 1500-1995. Int J Clim 31:696-703. https ://doi.org/10.1002/joc.2097, 2011.

HELCOM: Environment of the Baltic Sea area 1994-1998. Baltic Sea Environment Proceedings No. 82 B., 215 p. Helsinki 730 Commission, Helsinki, Finland, 2002.

Hemmer-Hansen, J., Hüssy, K., Baktoft, H., Huwer, B., Bekkevold, D., Haslob, H., Herrmann, J., Hinrichsen, H., Krumme, U., Mosegaard, H., Eg Nielsen, E., Reusch, T. B. H., Storr-Paulsen, M., Velasco, A., von Dewitz, B., Dierking, J. and Eero, M.: Genetic analyses reveal complex dynamics within a marine fish management area. Evolutionary Applications, 12: 830844, 2019.

735 Hinrichsen, H.-H., Lehmann, A., Petereit, C. and Schmidt, J.: Correlation analysis of Baltic Sea winter water mass formation and its impact on secondary and tertiary production. Oceanologia, 49(3), 381 - 395, 2007. 
Hinrichsen, H.-H., Voss, R., Wieland, K., Köster, F., Andersen, K.H. and Margonski, P.: Spatial and temporal heterogeneity of the cod spawning environment in the Bornholm Basin, Baltic Sea. Mar. Ecol. Prog. Ser. 345, 245 - 254, 2007.

Hinrichsen, H.-H., Lehmann, A., Petereit, C., Nissling, A., Ustups, D., Bergström, U., and Hüssy, K.: Spawning areas of eastern Baltic cod revisited: Using hydrodynamic modelling to reveal spawning habitat suitability, egg survival probability, and connectivity patterns. Progress in Oceanography, 143: 13-25, 2016a.

Hinrichsen, H. H., von Dewitz, B., Dierking, J. , Haslob, H., Makarchouk, A. , Petereit, C. and Voss, R.: Oxygen depletion in coastal seas and the effective spawning stock biomass of an exploited fish species. Royal Society Open Science 3: 150338, 2016b.

Höflich, K.and Lehmann, A.: Decadal variations in barotropic inflow characteristics and their relationship with Baltic Sea salinity variability. International Baltic Earth Secretariat Publications, Conference proceedings No. 13, 25-26, 2018.

Holtermann, P. L., Prien, R., Naumann, M., Mohrholz, V., Umlauf, L.:Deepwater dynamics and mixing processes during a major inflow event in the central Baltic Sea. J. Geophys. Res. Oceans, 122, 6648 - 6667,doi:10.1002/2017/JC013050, 2017. Hordoir, R., Axell, L., Löptien, U., Dietze, H., and Kuznetsov, I.: Influence of sea level rise on the dynamics of salt inflows in the Baltic Sea. Journal of Geophysical Research - Oceans 120(10), 6653-6668. https://doi.org/10.1002/2014JC010642, 2015.

Hurrel, J.W.: Transient eddy forcing of the rotational flow during northern winter. J. Atmos. Sci. 52:2286 - 2301, 1995.

Hurrel, J.W. and Deser, C.: North Atlantic climate variability: the role of the North Atlantic Oscillation. J. Mar. Syst. 78: 28 $-41,2009$.

Hünicke, B., Zorita, E., Soomere, T., Madsen , K.S. Johansson, M. and Suusaar, Ü.: Recent Change-Sea level and wind waves. In Second Assessment of Climate Change for the Baltic Sea Basin, pp. 155-185. Ed. by BACC II Author team. Springer, Springer Cham, Heidelberg, New York, Dordrecht, London, 501 pp., 2015.

Hüssy, K.: Review of western Baltic cod (Gadus morhua) recruitment dynamics. ICES Journal of Marine Science, 68: 14591471, 2011.

Hüssy, K., Hinrichsen, H.-H., Eero, M., Mosegaard, H., Hemmer-Hansen, J. Lehmann, A., and Lundgaard, L.S.: Spatiotemporal trends in stock mixing of eastern and western Baltic cod in the Arkona Basin and the implications for recruitment. ICES Journal of Marine Science, 73, 293-303, 2015.

IPCC, 2019: Summary for Policymakers. In: Climate Change and Land: an IPCC special report on climate change, desertification, land degradation, sustainable land management, food security, and greenhouse gas fluxes in terrestrial ecosystems [P.R. Shukla, J. Skea, E. Calvo Buendia, V. Masson-Delmotte, H.-O. Pörtner, D. C. Roberts, P. Zhai, R. Slade, S. Connors, R. van Diemen, M. Ferrat, E. Haughey, S. Luz, S. Neogi, M. Pathak, J. Petzold, J. Portugal Pereira, P. Vyas, E. Huntley, K. Kissick, M. Belkacemi, J. Malley, (eds.)]. In press.

Jakimavičius D., Kriaučiūnienė J. and Šarauskienė D.: Impact of climate change on the Curonian Lagoon water balance components, salinity and water temperature in the 21st century. Oceanologia. Volume 60, Issue 3. 378-389, 2018. 
770 Kanoshina, I., Lips, U., and Leppänen, J.-M.: The influence of weather conditions (temperature and wind) on cyanobacterial bloom development in the Gulf of Finland (Baltic Sea). Harmful Algae 2, 29-41. doi:10.1016/S1568-9883(02)00085-9, 2003.

Keevallik, S., and Soomere, T.: Regime shifts in the surface-level average air flow over the Gulf of Finland during 19812010. Proc. Est. Acad. Sci. 63, 428-437. doi:10.3176/proc.2014.4.08, 2014.

775 Kikas, V., and Lips, U.: Upwelling characteristics in the Gulf of Finland (Baltic Sea) as revealed by Ferrybox measurements in 2007-2013. Ocean Sci. 12, 843-859. doi:10.5194/os-12-843-2016, 2016.

Kniebusch, M., H. E. M. Meier,Neumann, T. and Börgel, F.: Temperature variability of the Baltic Sea since 1850 in model simulations and attribution to atmospheric forcing. Journal of Geophysical Research - Oceans, 124, 4168 - 4187. https://doi.org/10.1029/2018JCO13948, 2019a.

780 Kniebusch, M., Meier, H. E. M., \& Radtke, H.: Changing salinity gradients in the Baltic Sea as a consequence of altered freshwater budgets. Geophysical Research Letters, 46(16), 9739-9747, 2019b.

Köster, F. W., Huwer, B., Hinrichsen, H.-H., Neumann, V., Makarchouk, A., Eero, M., von Dewitz, B., Hüssy, K., et al.: Eastern Baltic cod recruitment revisited—dynamics and impacting factors. ICES Journal of Marine Science, 74(1), 3-19, 2017.

785 Laakso, L., Mikkonen, S., Drebs, A., Karjalainen, A., Pirinen, P., and Alenius, P.: 100 years of atmospheric and marine observations at the Finnish Utö Island in the Baltic Sea. Ocean Sci. 14, 617-632. doi:10.5194/os-14-617-2018, 2018.

Laanearu, J., Lips, U., and Lundberg, P.: On the application of hydraulic theory to the deep-water flow through the Irbe Strait. J. Mar. Syst. 25, 323-332. doi:10.1016/S0924-7963(00)00025-7, 2000.

Laine, A. O., Andersin, A.-B., Leiniö, S., and Zuur, A. F.: Stratification-induced hypoxia as a structuring factor of macrozoobenthos in the open Gulf of Finland (Baltic Sea). J. Sea Res. 57, 65-77. doi:10.1016/j.seares.2006.08.003, 2007. Lehmann, A., and Hinrichsen, H.-H.: On the thermohaline variability of the Baltic Sea. J. Mar. Syst. 25, 333 - 357, 2000. Lehmann, A., Krauss, W., and Hinrichsen, H.-H.: Effects of remote and local atmospheric forcing on circulation and upwelling in the Baltic Sea. Tellus 54A, 299-316, 2002.

Lehmann, A., Getzlaff, K., and Harlaß, J.: Detailed assessment of climate variability on the Baltic Sea area for the period 7951958 to 2009. Climate Research 46, 185 - 196, 2011.

Lehmann, A., Myrberg, K., and Höflich, K.: A statistical approach to coastal upwelling in the Baltic Sea based on the analysis of satellite data for 1990-2009. Oceanologia 54(3): 369-393, 2012.

Lehmann, A., and Post P.: Variability of atmospheric circulation patterns associated with large volume changes of the Baltic Sea. Advances in Science \& Research. do:10.5194/asr-12-219-2015, 2015.

800 Lehmann, A., Höflich, K., Post, P., and Myrberg, K.: Pathways of deep cyclones associated with large volume changes (LVCs) and major Baltic inflows (MBIs). Journal of Marine Systems 167, 11 - 18, 2017.

Lehtoranta, J., Savchuk, O. P., Elken, J., Dahlbo, K., Kuosa, H., Raateoja, M., et al.: Atmospheric forcing controlling interannual nutrient dynamics in the open Gulf of Finland. J. Mar. Syst. doi:10.1016/j.jmarsys.2017.02.001, 2017. 
Leppäranta M., and Myrberg, K.: Physical Oceanography of the Baltic Sea. Springer-Verlag, 378 pp., 2009.

Lessin, G., Raudsepp, U., and Stips, A.: Modelling the Influence of Major Baltic Inflows on Near-Bottom Conditions at the Entrance of the Gulf of Finland. PLoS One 9, e112881. doi:10.1371/journal.pone.0112881, 2014.

Liblik, T., and Lips, U.: Characteristics and variability of the vertical thermohaline structure in the Gulf of Finland in summer. Boreal.Environ.Res 16A, 73-83, 2011.

Liblik, T., and Lips, U.: Stratification has strengthened in the Baltic Sea - An analysis of 35 years of observational data.

Frontiers in Earth Science, 7:174. doi:10.3389/feart.2019.00174, 2019.

Liblik, T., Laanemets, J., Raudsepp, U., Elken, J., and Suhhova, I.: Estuarine circulation reversals and related rapid changes in winter near-bottom oxygen conditions in the Gulf of Finland, Baltic Sea. Ocean Sci. 9, 917-930, 2013.

Liblik, T., and Lips, U.: Variability of synoptic-scale quasi-stationary thermohaline stratification patterns in the Gulf of Finland in summer 2009. Ocean Sci. 8, 603-614. doi:10.5194/os-8-603-2012, 2012.

815 Liblik, T., and Lips, U.: Variability of pycnoclines in a three-layer, large estuary: the Gulf of Finland. Boreal Environ. Res. 22, 27-47, 2017.

Liblik, T., Naumann, M., Alenius, P., Hansson, M., Lips, U., Nausch, G., Tuomi, L., Wesslander, K., Laanemets J., and Viktorsson, L.: Propagation of Impact of the Recent Major Baltic Inflows From the Eastern Gotland Basin to the Gulf of Finland. Frontiers of Marine Sciences., https://doi.org/10.3389/fmars.2018.00222, 2018.

Liblik, T., Skudra, M., and Lips, U.: On the buoyant sub-surface salinity maxima in the Gulf of Riga. Oceanologia 59, 113128. doi:10.1016/J.OCEANO.2016.10.001, 2017.

Lilover, M.-J., Elken, J., Suhhova, I., and Liblik, T.: Observed flow variability along the thalweg, and on the coastal slopes of the Gulf of Finland, Baltic Sea. Estuar. Coast. Shelf Sci. doi:10.1016/j.ecss.2016.11.002, 2016.

Lilover, M.-J., Lips, U., Laanearu, J., and Liljebladh, B.: Flow regime in the Irbe Strait. Aquat. Sci. 60, 253. doi:10.1007/s000270050040, 1998.

Lips, I., Lips, U., and Liblik, T.: Consequences of coastal upwelling events on physical and chemical patterns in the central Gulf of Finland (Baltic Sea). Cont. Shelf Res. 29, 1836-1847. doi:10.1016/j.csr.2009.06.010, 2009.

Lips, U., Kikas, V., Liblik, T., and Lips, I.: Multi-sensor in situ observations to resolve the sub-mesoscale features in the stratified Gulf of Finland, Baltic Sea. Ocean Sci. 12, 715-732. doi:10.5194/os-12-715-2016, 2016a.

830 Lips, U., Laanemets, J., Lips, I., Liblik, T., Suhhova, I., and Suursaar, Ü.: Wind-driven residual circulation and related oxygen and nutrient dynamics in the Gulf of Finland (Baltic Sea) in winter. Estuar. Coast. Shelf Sci. 195, 4-15. doi:10.1016/ J.ECSS.2016.10.006, 2017.

Lips, U., Zhurbas, V., Skudra, M., and Väli, G.: A numerical study of circulation in the Gulf of Riga, Baltic Sea. Part I: Whole-basin gyres and mean currents. Cont. Shelf Res. 112, 1-13. doi:10.1016/J.CSR.2015.11.008, 2016b.

835 Lips, U., Zhurbas, V., Skudra, M., and Väli, G.: A numerical study of circulation in the Gulf of Riga, Baltic Sea. Part II: Mesoscale features and freshwater transport pathways. Cont. Shelf Res. 115, 44-52. doi:10.1016/j.csr.2015.12.018, 2016c. 
https://doi.org/10.5194/esd-2021-15

Preprint. Discussion started: 4 June 2021

(c) Author(s) 2021. CC BY 4.0 License.

Maljutenko, I., and Raudsepp, U.: Long-term mean, interannual and seasonal circulation in the Gulf of Finland — The wide salt wedge estuary or gulf type ROFI. J. Mar. Syst. 195, 1-19. doi:10.1016/J.JMARSYS.2019.03.004, 2019.

Marmefelt, E., and Omstedt, A.: Deep water properties in the Gulf of Bothnia. Continental Shelf Research, 13, Issues 2-3, 169-187, 1993.

Matthäus, W., Nehring D., Feistel, R., Nausch, G., Mohrholz, V., and Lass, H.U.: The inflow of highly saline water into the Baltic Sea. In State and Evolution of the Baltic Sea, 1952 - 2005: A detailed 50-year survey of meteorology and climate, physics, chemistry, biology and marine environment. Wiley, 2008.

Matthäus, W., and Franck, H.: Characteristics of major Baltic inflows:A statistical analysis. Continental Shelf Research, 12, $8451375-1400,1992$.

Matthäus, W. and Schinke, H.: Mean atmospheric circulation patterns associated with major Baltic inflows. Deutsche Hydrographische Zeitschrift 46, 321-339, 1994

Meier, H.E.M.: Modeling the pathways and ages of inflowing salt- and freshwater in the Baltic Sea. Estuarine, Coastal and Shelf Science 74(4), 610-627, 2007.

Meier, H. E. M., and Döscher, R.: Simulated water and heat cycles of the Baltic Sea using a 3D coupled atmosphere-iceocean model. Boreal Env. Res., 7, 327-334, 2002.

Meier, H. E. M., and Kauker, F.: Modeling decadal variability of the Baltic Sea: 2. Role of freshwater inflow and large-scale atmospheric circulation for salinity. J. Geophys. Res., 108(C11), 3368, doi:10.1029/2003JC001799, 2003.

Meier, H.E.M, Andersson, H.C., Arheimer, B., Donnelly, C., Eilola, K., Gustafsson, B.G., Kotwicki, L., et al.: Ensemble modeling of teh Baltic Sea ecosystem to provide scenarios for management. Ambio 43 (1) , 37 - 48., doi:10.1007/s13280013-0475-6, 2014.

Meier, H. E. M., Höglund, A., Almroth-Rosell, E., and Eilola, K.: Impact of accelerated future global mean sea level rise on hypoxia in the Baltic Sea. Climate Dynamics, 49, 163-172, https://doi.org/10.1007/s00382-016-3333-y, 2017.

Meier, H. E. M., Eilola, K., Almroth-Rosell, E., Schimanke, S., Kniebusch, M., Höglund, A., Pemberton, P., Y. Liu, Y., Väli, G., and Saraiva, S.: Disentangling the impact of nutrient load and climate changes on Baltic Sea hypoxia and eutrophication since 1850. Climate Dynamics, 1-22, https://doi.org/10.1007/s00382-018-4296-y, 2019a.

Meier, H. E. M., K. Eilola, E. Almroth-Rosell, S. Schimanke, M. Kniebusch, A. Höglund, P. Pemberton, Y. Liu, G. Väli, and S. Saraiva, 2019b: Correction to: Disentangling the impact of nutrient load and climate changes on Baltic Sea hypoxia and eutrophication since 1850. Climate Dynamics, 53:1167-1169, https://doi.org/10.1007/s00382-018-4483-x, 2019b.

865 Merkouriadi, I., and Leppäranta, M.: Long-term analysis of hydrography and sea-ice data in Tvärminne, Gulf of Finland, Baltic Sea. Clim. Change 124, 849-859. doi:10.1007/s10584-014-1130-3. 2014.

Mikulski Z.: Inflow from drainage basin, in Water Balance of the Baltic Sea-Baltic Sea Environment Proceedings 16, pp 2434, Baltic Mar. Environ. Prot. Comm., Helsinki, Finland, 1986.

Mohrholz, V., Naumann, M., Nausch, G., Krüger, S., and Gräwe, U... Fresh oxygen for the Baltic Sea - An exceptional saline inflow after a decade of stagnation. J. Mar. Syst. 148, 152-166. doi:10.1016/j.jmarsys.2015.03.005, 2015. 
https://doi.org/10.5194/esd-2021-15

Preprint. Discussion started: 4 June 2021

(c) Author(s) 2021. CC BY 4.0 License.

(c) (i)

Mohrholz, V.: Major Baltic Inflow Statistics - Revised. Frontiers in Marine Science 5, 384. https://doi.org/10.3389/fmars.2018.00384, 2018.

Matulla, C., Schöner, W., Alexandersson, H., von Storch, H., and Wang, X.L. : European storminess: Late nineteenth century to present. Climate Dyn., 31, 125-130, https://doi.org/10.1007/s00382-007-0333-y, 2008.

Myrberg, K.: Analysing and modelling the physical processes of the Gulf of Finland in the Baltic Sea. Monographs of the Boreal Environment Research, 10, University of Helsinki, Faculty of Science. 50 pp. +5 articles (PhD-Thesis), Finnish Institute of Marine Research, Helsinki. 1998.

Myrberg, K., and Andrejev, O.: Main upwelling regions in the Baltic Sea -a statistical analysis based on three-dimensional modelling. Boreal Environment Research 8(2): 97-112, 2003.

880 Myrberg, K., and Andrejev O.: Modelling of the circulation, water exchange and water age properties of the Gulf of Bothnia. Oceanologia 48 (S): 55-74, 2006.

Naumann, M., Mohrholz, V., and Waniek, J. J.: Water Exchange and conditions in the Deep Basins. HELCOM Balt. Sea Environ. Fact Sheets. Online, 2018.

Nehring, D., and Matthäus, W.: Current trends in hydrographic and chemical parameters and eutrophication in the Baltic

Sea. Internationale Revue der gesamten Hydrobiologie und Hydrographie, 76(3), 297-316., 1991.

Neumann, T., Radtke, H., and Seifert, T. : On the importance of Major Baltic Inflows for oxygenation of the central Baltic Sea. Journal of Geophysical Research, Oceans, 122, 1090-1101 https://doi.org/10.1002/2016JC012525, 2017.

Nielsen, M. H.: Evidence for internal hydraulic control in the northern Øresund, J. Geophys. Res., 106(C7), 14,055-14,068, 2001.

890 Nilsson, J., Andersson, J., Karås, P. \& Sandström, O.: Recruitment failure and decreasing catches of perch (Perca fluviatilis L.) and pike (Esox lucius L.) in the coastal waters of southeast Sweden. Boreal Env. Res. 9: 295-306, 2004.

Nissling, A., Kryvi, H., and Vallin, L.: Variation in egg buoayancy of Baltic cod Gadus morhua and its implications for egg survival in prevailing conditions in the Baltic Sea. Marine Ecology Progress Series, 110: 67-74, 1994.

Nissling, A., and Westin, L.: Salinity requirements for successful spawning of Baltic and Belt Sea cod and the potential for cod stock interactions in the Baltic Sea. Marine Ecology Progress Series, 152: 261-271, 1997.

Omstedt, A., Elken, J. Lehmann, A., and Piechura, J.: Knowledge of the Baltic Sea physics gained during the BALTEX and related programmes. Progress in Oceanography 63, 1-28, 2004.

Omstedt, A., Elken, J., Lehmann, A., Leppäranta, M., Meier, H. E. M., Myrberg, K., and Rutgersson, A.: Progress in physical oceanography of the Baltic Sea during the 2003-2014 period. Progress in Oceanography, 128, 139-171, 2014.

900 Otsmann, M., Suursaar, Ü., and Kullas, T.: The oscillatory nature of the flows in the sysem of straits and small semienclosed basins of the Baltic Sea. Continental Shelf Res., 21, 1577 -1603, 2001.

Pinto, J. G., and Raible, C.C.: Past and recent changes in the North Atlantic oscillation. WIREs Clim Change, 3, 79-90, https://doi.org/10.1002/wcc.150, 2012. 
Post, P., and Lehmann, A.:Assessment of long time series of atmospheric circulation patterns forcing large volume changes and major inflows to the Baltic Sea. International Baltic Earth Secretariat Publication No. 9, Conference Proceedings, 28 29, 2016.

Raateoja, M.: Deep-water oxygen conditions in the Bothnian Sea. Boreal Env. Res. 18: 235-249, 2013.

Rak, D.: The inflow in the Baltic Proper as recorded in January-February 2015. Oceanologia, 58 (3), 241-247. https://doi.org/10.1016/j.oceano.2016.04.001, 2015.

910 Raudsepp, U.: Interannual and seasonal termperature and salinity variations in the Gulf of Riga and corresponding saline water inflow from the Baltic Proper. Nordic Hydrology32, 2:135 - 160, 2001.

Reissmann, J.H., Burchard, H., Feistel,R., Hagen, E., Lass, H.U., Mohrholz, V., Nausch, G., Umlauf, L.,and Wiecczorek, G.: Vertical mixing in the Baltic Sea and consequences for eutrophication a review. Prog. Oceanogr. 82, 47 - 80. https://dxdoi.org/10.1016/jpocean.2007.10.004, 2009.

915 Rózyn’ski G., Bielecka M., Margon’ski P., Psuty I., Szymanek L., Chubarenko B., Esiukova E., Domnin D., Domnina A., and Pilipchuk V.: The physio-geographical background and ecology of the Vistula Lagoon. Coastal Lagoons in Europe Integrated Water Resource Strategies (Edited by Ana I. Lillebø, Per Stålnacke and Geoffrey D. Gooch). IWA Publishing. 5767, 2018.

Ruzzante, D.E., Mariani, S., Bekkevold, D., André, C. et al.: Biocompexity in a high migratory pelagic marine fish, Atlantic herring. Proc. R. Soc. B. 273:1459-1464, 2006.

Saraiva, S., Meier, H. E. M., Andersson, H. C., Höglund, A., Dieterich, C., Gröger, M., Hordoir, R., and Eilola, K.: Uncertainties in projections of the Baltic Sea ecosystem driven by an ensemble of global climate models. Frontiers in Earth Science, 6:244, https://doi.org/10.3389/feart.2018.00244, 2019b.

Schimanke, S., Dieterich, C., and Meier, H.E.M.: An algorithm based on SLP- fluctuations to identify major Baltic inflow events. Tellus A, 66, 23452, http://dx.doi.org/10.3402/tellusa.v66, 2014.

Schimanke, S., and Meier, H.E.M.: Decadal to centennial variability of salinity in the Baltic Sea. Journal of Climate, 29(20), 7173-7188. http://dx.doi.org/10.1175/JCLI-D-15-0443.1, 2016.

Schinke, H., and Matthäus, W.: On the causes of major Baltic inflows-an analysis of long time series. Continental Shelf Research 18, 67-97, 1998.

930 Skudra, M., Lips, U.: Characteristics and inter-annual changes in temperature, salinity and density distributions in the Gulf of Riga. Oceanologia, 59, 1, 37 - 48, 2017.

Soomere, T., Myrberg, K., Leppäranta, M., and Nekrasov, A.: Progress in knowledge of the physical oceanography of the Gulf of Finland: a review for 1997-2007. Oceanologia 50 (3), 287-362, 2008.

Soomere, T., Bishop, S.R., Viska, M., and Räämet, A.: An abrupt change in winds that may radically affect the coasts and 935 deep sections of the Baltic Sea. Climate Research, 62(2), 163 - 171., doi:10.3354/cr01269, 2015.

Soosaar, E., Maljutenko, I., Raudsepp, U., and Elken, J.: An investigation of anticyclonic circulation in the southern Gulf of Riga during spring period. Cont. Shelf Res., 78, 75 - 84, 2014. 
Soosaar, E. Maljtenko, I., Uiboupin, R., Skudra, M., and Raudsepp, U.: River bulge evolution and dynamics in a non-tidal sea - Daugava River plume in the Gulf of Riga, Baltic Sea. Ocean Sci., 12, 417 - 432, 2016.

Stepanova, N.B.: Vertical structure and seasonal evolution of the cold intermediate layer in the Baltic Proper. Estuar. Coast. Shelf Sci. 195, 34-40. DOI: 10.1016/j.ecss.2017.05.011, 2017.

Stipa, T., Tamminen, T., Seppälä, J.: On the creation and maintenance of startification in the Gulf of Riga. J. Marine Syst., 23 (1-3), 27 - 49, 1999.

Stoicescu, S.-T., Lips, U., and Liblik, T.: Assessment of Eutrophication Status Based on Sub-Surface Oxygen Conditions in the Gulf of Finland (Baltic Sea). Front. Mar. Sci. 6:54. doi: 10.3389/fmars.2019.00054, 2019.

Stramska, M., and Aniskiewicz, P.: Satellite Remote Sensing Signatures of the Major Baltic Inflows Remote Sensing, 11(8), 954; https://doi.org/10.3390/rs11080954, 2019.

Suhhova, I., Liblik, T., Madis-Jaak, L., and Urmas, L.: A descriptive analysis of the linkage between the vertical stratification and current oscillations in the Gulf of Finland. Boreal Environmental Research, 23, 83 - 103, 2018.

Svedäng, H., Righton, D., and Jonsson, P.: Migratory behavior of Atlantic cod Gadus morhua: natal homing is the prime stock separating mechanism. Marine Ecology Progress Series, 345: 1-12, 2007.

Tuomi, L., Miettunen, E., Alenius, P., and Myrberg, K.: Evaluating hydrography, circulation and transport in a coastal archipelago using a high-resolution 3D hydrodynamic model. Journal of Marine Systems, 180, 24-36. 2018.

Vankevich, R.E., Sofina, E.V., Eremina, T.E., RyabchenkoV.A., Molchanov, M.S., and Isaev, A.V.: Effects of

955 lateralprocesses on the seasonal water stratification of the Gulf of Finland: 3-D NEMO-bsed model study. Ocean Sci. 12, 987 - 1001, 2016.

Vuorinen, I., Hänninen, J., Rajasilta, M., Laine, P., Eklund, J., Montesino-Pouzols, F., Corona, F., Junker, K., Meier, H.E.M., and Dippner, J.W.: Scenario simulations of future salinity and Ecological Consequences in the Baltic Sea and adjacent North Sea areas - implications for environmental monitoring. Ecological Indicators, 50, 196 - 205, 2015.

960 Wallace, J.M., and Gutzler, D.S.: Teleconnections in the geopotential height field during the northern hemisphere winter. Mon. Weather Rev. 109: 784 - 812, 1981.

Waltz, M.A., Befort, D.J., Kirchner-Bossi, N.O., Ulbrich, U., and Leckebusch, G.C.: Modelling serial clustering and internannual variability of European winter windstorms based on large-scale drivers. Int. J. Climatol. 38, 3044 - 3057, 2018.

Winsor, P., Rodhe, J., and Omstedt, A.:Baltic Sea ocean climate: an analysis of 100 yr of hydrographic data with focus on 965 the freshwater budget. Climate Research, 18(1-2), 5-15, 2001.

Winsor, P., Rodhe, J., and Omstedt, A.: Erratum: Baltic Sea ocean climate: an analysis of 100 yr of hydrographical data with focus on the freshwater budget. Climate Research 25:183, 2003.

Wieland K., Waller, U., and Schnack, D.: Development of Baltic cod eggs at different levels of temperature and oxygen content. Dana 10: 163-177, 1994.

970 Wieland, K., and Jarre-Teichmann, A.: Prediction of vertical distribution and ambient development temperature of Baltic cod, Gadus morhua L, eggs. Fisheries Oceanography, 6: 172-176, 1997. 
https://doi.org/10.5194/esd-2021-15

Preprint. Discussion started: 4 June 2021

(c) Author(s) 2021. CC BY 4.0 License.

(c) (1)

\section{Earth System \\ Dynamics}

Discussions

Zhurbas, V., Väli, G., Golenko, M., and Paka, V.: Variability of bottom friction velocity along the 450 inflow water pathway in the Baltic Sea, Journal of Marine Systems, 184, 50-58, https://doi: 10.1016/j.jmarsys.2018.04.008, 2018.

Zubiate, L., McDermott, F., Sweeney, C., and O’Malley, M.: Spatial variability in winter NAO-wind speed relationships in western Europe linked to concomitant states of the East Atlantic and Scandinavian patterns. Quaterly Journal of teh Royal Meteorological Society 143, 552 - 562, https://doi.org/10.1002/qj.2943, 2016. 
https://doi.org/10.5194/esd-2021-15

Preprint. Discussion started: 4 June 2021

(c) Author(s) 2021. CC BY 4.0 License.

\section{Earth System \\ Dynamics \\ Discussions}

\section{Figures}

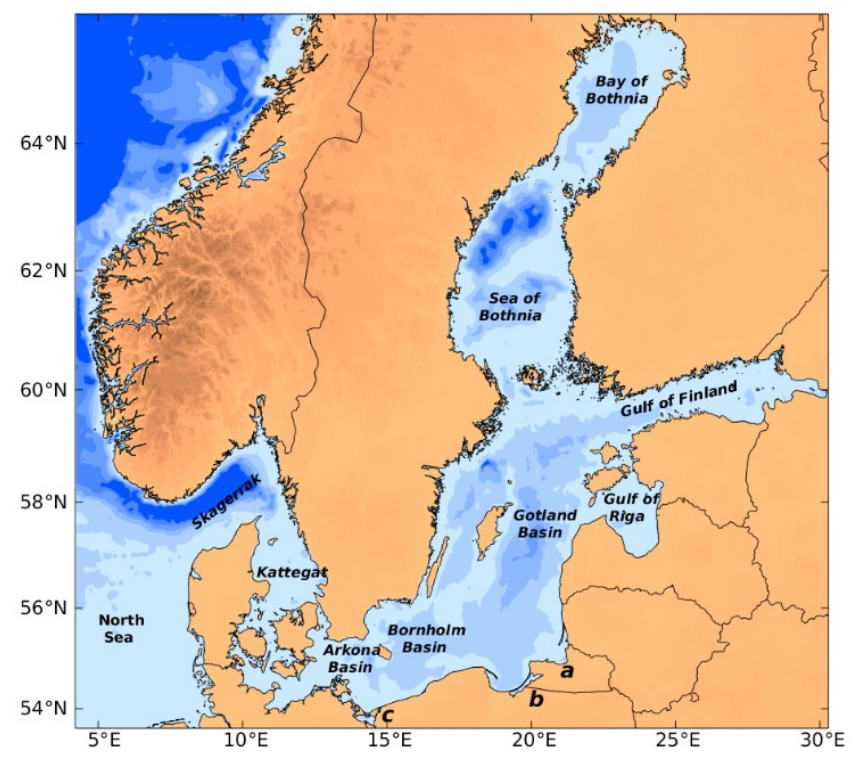

Figure 1: Map of the Baltic Sea and its sub-basins. The Baltic Proper comprises the sub-basins: Arkona, Bornholm and Gotland Basin. The Gulf of Bothnia comprises the Sea of Bothnia and the Bay of Bothnia. (a), (b) and (c) denote the Curonian, Vistula and Szczecin Lagoons. 

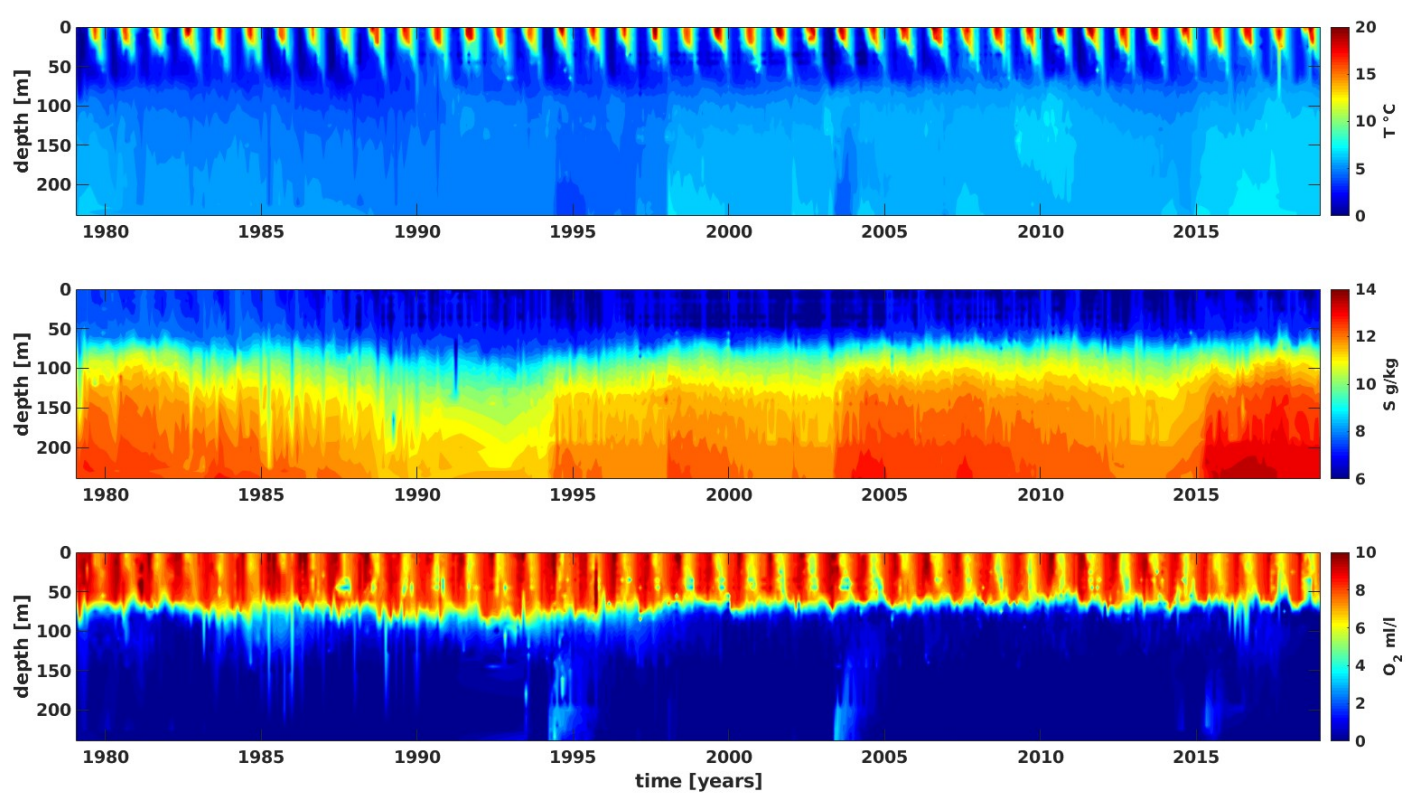

Figure 2. Time series of temperature (top), salinity (middle) and oxygen (bottom) of ICES profiles of Subdivision (SD) 28 (eastern Gotland Basin) for the period 1979-2018. 
https://doi.org/10.5194/esd-2021-15

Preprint. Discussion started: 4 June 2021

(c) Author(s) 2021. CC BY 4.0 License.

(c) (i)
Earth System

Dynamics

Discussions
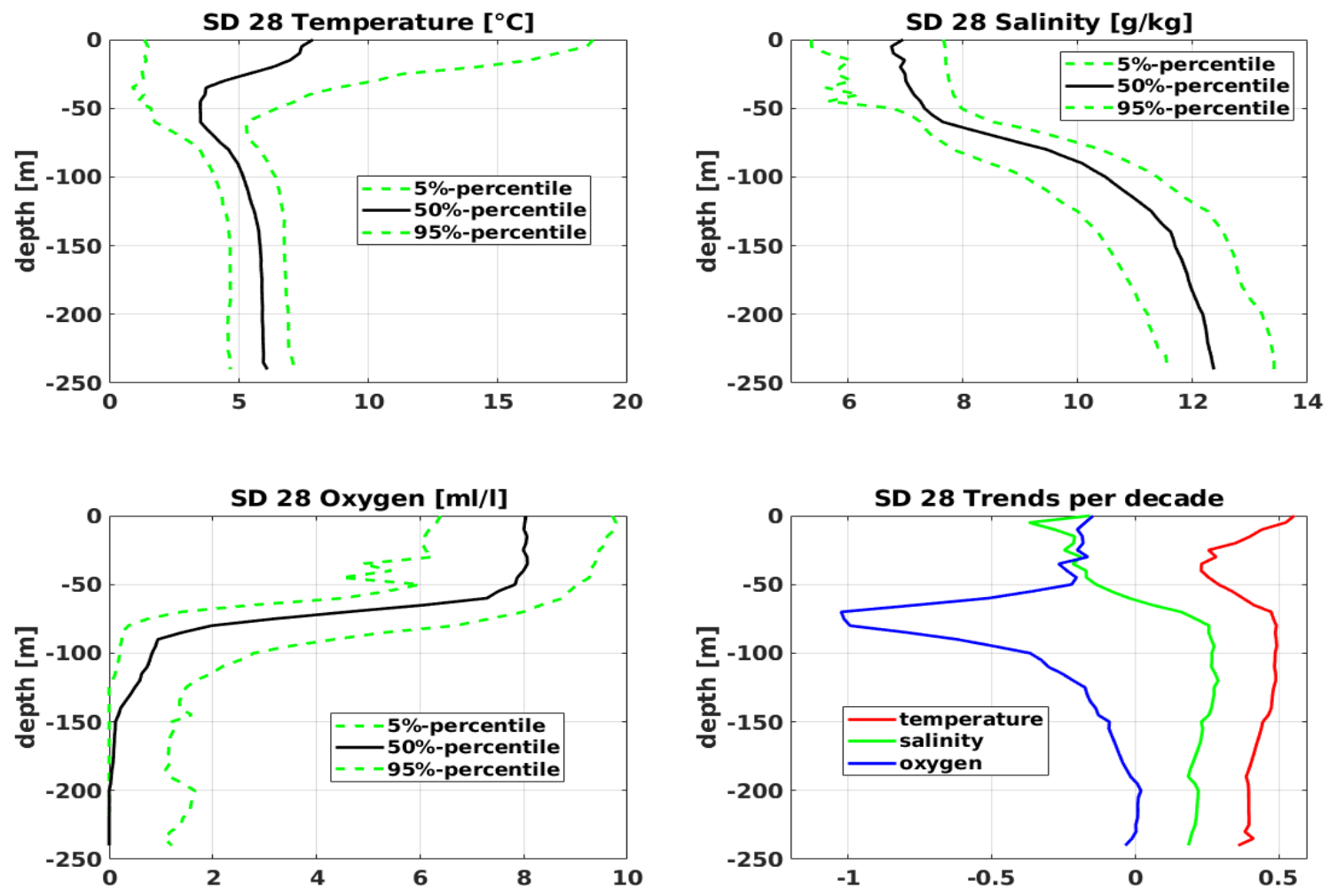

Figure. 3. Percentiles (5, 50 and 95\%) of temperature, salinity and oxygen profiles for SD 28 (eastern Gotland Basin) for the period 1979-2018. Trends per decade of temperature, salinity and oxygen based on SD 28 temperature, salinity and oxygen profiles for the period 1979-2018 (right lower panel). 
https://doi.org/10.5194/esd-2021-15

Preprint. Discussion started: 4 June 2021

(c) Author(s) 2021. CC BY 4.0 License.

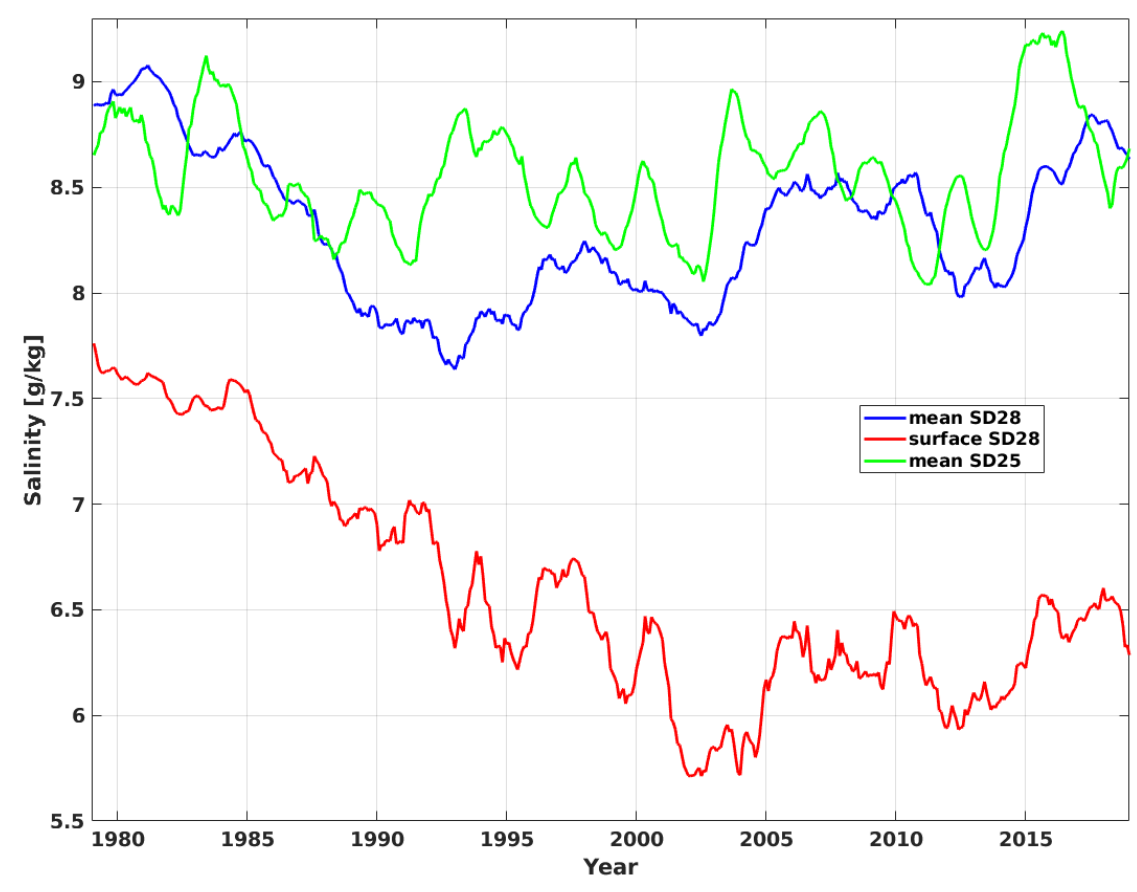

Figure 4. Mean salinity of SD 28 (eastern Gotland Basin) (blue) and surface salinity of SD 28 (red). For comparison mean salinity of SD 25 (Bornholm Basin) (green) for the period 1979-2018. All series 12 months running mean. 
https://doi.org/10.5194/esd-2021-15

Preprint. Discussion started: 4 June 2021

(c) Author(s) 2021. CC BY 4.0 License.

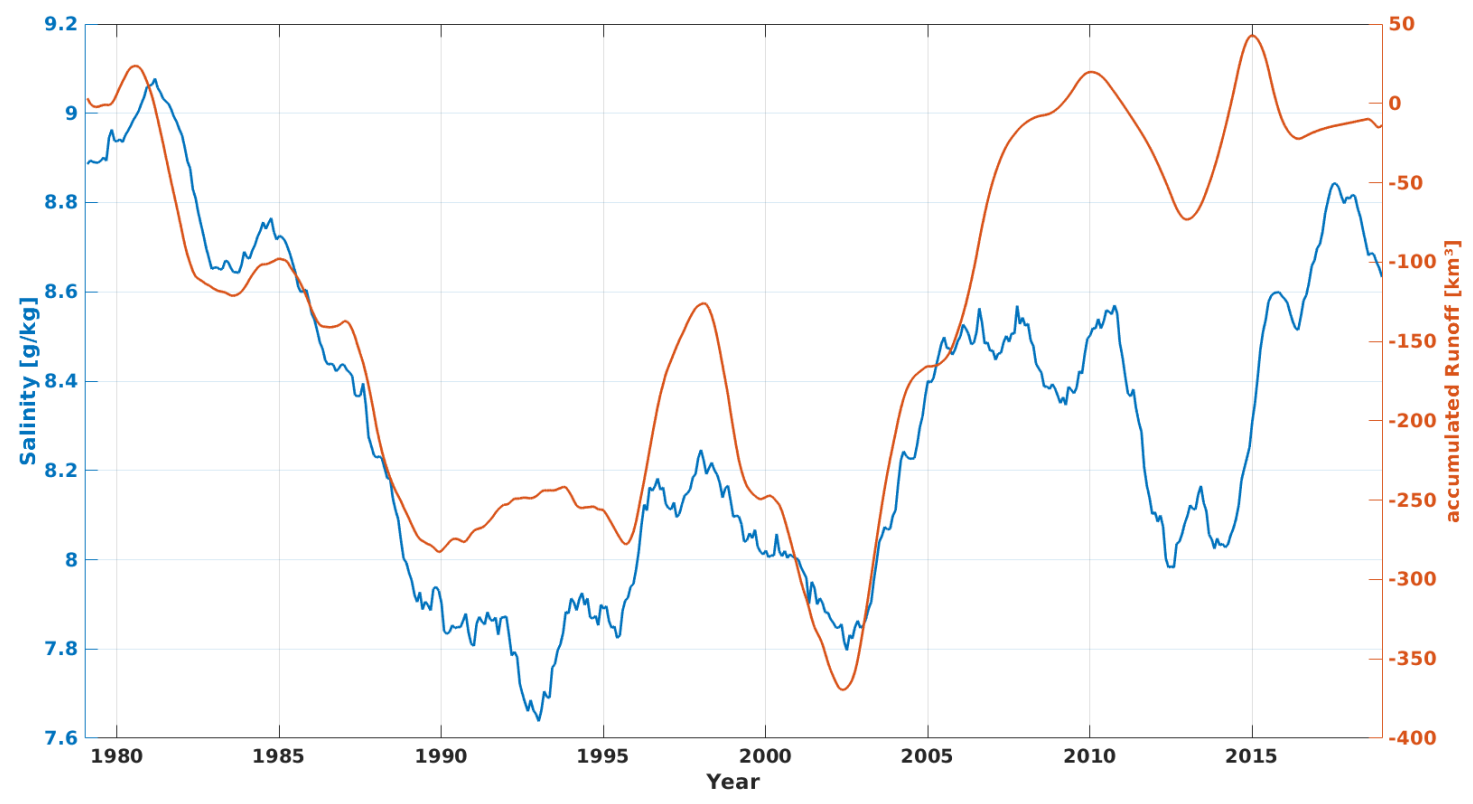

1110 Figure. 5. Volume averaged salinity of SD28 for the period 1979 to 2018 and accumulated anomalies of runoff to the Baltic Sea (inverted). The correlation coefficient is 0.75 . All series 12 months running mean. 